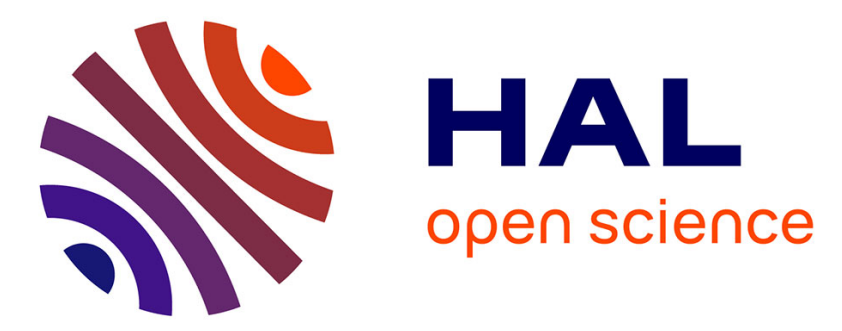

\title{
Study of the hydrogen diffusion and segregation into Fe-C-Mo martensitic HSLA steel using electrochemical permeation test
}

S. Frappart, X. Feaugas, Jordi Creus, F. Thebault, L. Delattre, H. Marchebois

\section{- To cite this version:}

S. Frappart, X. Feaugas, Jordi Creus, F. Thebault, L. Delattre, et al.. Study of the hydrogen diffusion and segregation into Fe-C-Mo martensitic HSLA steel using electrochemical permeation test. Journal of Physics and Chemistry of Solids, 2010, 71 (10), pp.1467. 10.1016/j.jpcs.2010.07.017 . hal-00671934

\section{HAL Id: hal-00671934 \\ https://hal.science/hal-00671934}

Submitted on 20 Feb 2012

HAL is a multi-disciplinary open access archive for the deposit and dissemination of scientific research documents, whether they are published or not. The documents may come from teaching and research institutions in France or abroad, or from public or private research centers.
L'archive ouverte pluridisciplinaire HAL, est destinée au dépôt et à la diffusion de documents scientifiques de niveau recherche, publiés ou non, émanant des établissements d'enseignement et de recherche français ou étrangers, des laboratoires publics ou privés. 


\section{Author's Accepted Manuscript}

Study of the hydrogen diffusion and segregation into Fe-C-Mo martensitic HSLA steel using electrochemical permeation test

S. Frappart, X. Feaugas, J. Creus, F. Thebault, L. Delattre, H. Marchebois

PII: $\quad$ S0022-3697(10)00218-0

DOI: doi:10.1016/j.jpcs.2010.07.017

Reference: PCS 6224

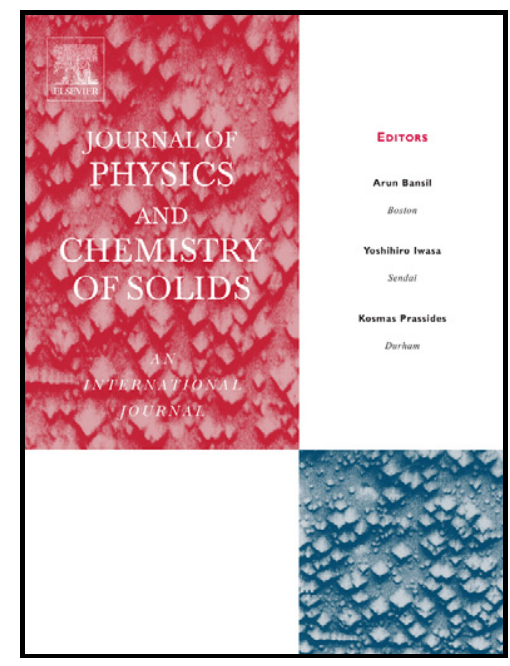

www.elsevier.com/locate/jpcs

To appear in: Journal of Physics and Chemistry of Solids

Received date: 16 March 2010

Revised date: 22 June 2010

Accepted date: 15 July 2010

Cite this article as: S. Frappart, X. Feaugas, J. Creus, F. Thebault, L. Delattre and H. Marchebois, Study of the hydrogen diffusion and segregation into Fe-C-Mo martensitic HSLA steel using electrochemical permeation test, Journal of Physics and Chemistry of Solids, doi:10.1016/j.jpcs.2010.07.017

This is a PDF file of an unedited manuscript that has been accepted for publication. As a service to our customers we are providing this early version of the manuscript. The manuscript will undergo copyediting, typesetting, and review of the resulting galley proof before it is published in its final citable form. Please note that during the production process errors may be discovered which could affect the content, and all legal disclaimers that apply to the journal pertain. 


\title{
Study of the hydrogen diffusion and segregation into Fe-C-Mo martensitic HSLA steel using electrochemical permeation test
}

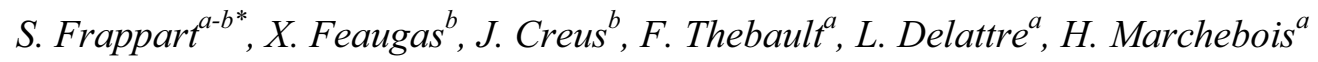 \\ ${ }^{a}$ V\&M France - VRA, 60 route de Leval, F-59620 Aulnoye-Aymeries, France \\ ${ }^{\mathrm{b}}$ LEMMA, Laboratoire d'Etudes des Matériaux en Milieux Agressifs, Université de la Rochelle, Avenue Michel \\ Crépeau, F-17042 La Rochelle cedex 01, France
}

*Corresponding author at :

LEMMA, Laboratoire d'Etudes des Matériaux en Milieux Agressifs, Université de La Rochelle, Avenue Michel Crépeau, F-17042 La Rochelle cedex 01, France

Tel. : 00335464583 52, Fax : 0033546457272

E-mail adress: simon.frappart@univ-lr.fr

\begin{abstract}
Diffusion and trapping mechanisms are studied in order to improve Hydrogen Embrittlement (HE) resistance of high yield strength steels. Investigations were carried on Fe-C-Mo model steel with a quenched and tempered martensitic microstructure. Hydrogen diffusion was studied by using the electrochemical permeation technique. The influence of the charging current densities in $1 \mathrm{M} \mathrm{H}_{2} \mathrm{SO}_{4}$ at ambient temperature shows a relation between the apparent diffusion coefficient $\mathrm{D}_{\text {app }}$ and the apparent subsurface concentration of hydrogen $\mathrm{C}_{0 \text { app. Two }}$ domains can be separated and are mainly associated with a competition between two distinct processes: hydrogen trapping and hydrogen diffusion. These results are correlated to the quantities of reversible and irreversible traps into the membrane. Moreover, the experimental results revealed that the apparent diffusion coefficient increases and the total amount of trapped hydrogen decreases with temperature. The activation energy of diffusion processes $(0.26 \mathrm{eV})$ and trapping processes $(0.58 \mathrm{eV})$ are supposed to be respectively affiliated with lattice diffusion and with trapping on incidental dislocations and/or on martensitic lath interfaces due to misorientations (geometric necessary dislocations).
\end{abstract}

\section{Keywords}

Hydrogen, Electrochemical Permeation, Diffusion, Trapping 


\begin{tabular}{|c|c|c|}
\hline \multicolumn{3}{|c|}{ Nomenclature } \\
\hline $\mathrm{j}$ & Measured current density & $\left(\mu \mathrm{A} / \mathrm{cm}^{2}\right)$ \\
\hline $\mathrm{j}_{\mathrm{ch}}$ & Charging current density & $\left(\mathrm{mA} / \mathrm{cm}^{2}\right)$ \\
\hline $\mathrm{j}_{\infty}$ & Steady-state permeation rate & $\left(\mu \mathrm{A} / \mathrm{cm}^{2}\right)$ \\
\hline $\mathrm{T}$ & Temperature & $(\mathrm{K})$ \\
\hline E & Potential & $(\mathrm{V})$ \\
\hline SHE & Standard Hydrogen Electrode & $(0 \mathrm{~V} / \mathrm{SHE})$ \\
\hline $\mathrm{D}_{\text {app }}$ & Apparent diffusion coefficient & $\left(\mathrm{m}^{2} / \mathrm{s}\right)$ \\
\hline $\mathrm{D}_{\mathrm{L}}$ & Lattice diffusion coefficient & $\left(\mathrm{m}^{2} / \mathrm{s}\right)$ \\
\hline$\tau$ & Dimensionless parameter & \\
\hline $\mathrm{L}$ & Thickness of the membrane & $(\mathrm{m})$ \\
\hline $\mathrm{C}_{0 \text { app }}$ & Apparent hydrogen subsurface concentration & (ppm wt) \\
\hline$<\mathrm{C}>$ & Average hydrogen concentration & $(\mathrm{ppm} w \mathrm{w})$ \\
\hline $\mathrm{C}_{\mathrm{H}}$ & Hydrogen concentration & (ppm wt) \\
\hline $\mathrm{C}_{\mathrm{L}}$ & Lattice hydrogen concentration & (ppm wt) \\
\hline $\mathrm{C}_{\mathrm{T}}$ & Total trapped hydrogen concentration & $(\mathrm{ppm} w \mathrm{wt})$ \\
\hline $\mathrm{C}_{\text {Tir }}$ & Irreversible trapped hydrogen concentration & (ppm wt) \\
\hline $\mathrm{C}_{\mathrm{Tr}}$ & Reversible trapped hydrogen concentration & (ppm wt) \\
\hline $\mathrm{N}_{\mathrm{L}}$ & Number of lattice sites per unit volume & $\left(\mathrm{m}^{-3}\right)$ \\
\hline $\mathrm{N}_{\mathrm{T}}$ & Number of trap sites per unit volume & $\left(\mathrm{m}^{-3}\right)$ \\
\hline$\theta_{\mathrm{L}}$ & The occupancy of lattice sites & \\
\hline$\theta_{\mathrm{T}}$ & The occupancy of trap sites & \\
\hline$E_{D}$ & Activation energy of diffusion process & $(\mathrm{eV})$ \\
\hline$\Delta \mathrm{E}_{\mathrm{L}}$ & $\begin{array}{l}\text { Activation energy for moving from a lattice site } \\
\text { to an adjacent lattice site }\end{array}$ & $(\mathrm{eV})$ \\
\hline$\Delta \mathrm{E}_{\mathrm{T}}$ & Trap binding energy & $(\mathrm{eV})$ \\
\hline$\Delta \mathrm{E}_{\mathrm{TL}}$ & $\begin{array}{l}\text { Activation energy for moving from a lattice site } \\
\text { to a trap site }\end{array}$ & $(\mathrm{eV})$ \\
\hline $\mathrm{k}_{\mathrm{B}}$ & Boltzmann constant & $8.617343 \times 10^{-5}(\mathrm{eV} / \mathrm{K})$ \\
\hline$\rho_{\mathrm{Fe}}$ & Iron density & $7.87\left(\mathrm{~g} / \mathrm{cm}^{3}\right)$ \\
\hline $\mathrm{F}$ & Faraday constant & $96485(\mathrm{C} / \mathrm{mol})$ \\
\hline $\mathrm{M}_{\mathrm{H}}$ & Molar mass of hydrogen & $1(\mathrm{~g} / \mathrm{mol})$ \\
\hline
\end{tabular}




\section{Introduction}

Hydrogen Embrittlement (HE) is a phenomenon responsible for premature failure of steel structures, for instance for petroleum industries under "sour service" environment $\left(\mathrm{H}_{2} \mathrm{~S}\right.$ content). In the context of environmental sustainability, it is compelling to improve or conceive new processes and/or new materials able to reduce the susceptivity to HE. These damages can be linked to hydrogen diffusion and trapping into the metal. Hydrogen is the subject of many fundamental and applied researches in physics and chemistry. It is essentially studied in industrial research due to hydrogen embrittlement that may occur in industrial environments. The interactions of this element with the metallic structure are often analyzed using permeation tests. The effect of thickness [1-4], the effect of an oxide layer [5-7], the use of a palladium coating [8-12], the influence of temperature to determine the diffusion activation energy [7] and finally the effect of the microstructure of low carbon steels [4, 12-22] had already been discussed in several papers. The electrochemical permeation experiment allows to easily measure the hydrogen flux through a metallic membrane and so is a relevant technique to characterize the hydrogen-metal system. Moreover, to access the real diffusion coefficient, the average concentration and trapped hydrogen, fundamental hypothesis are generally established to explain experimental data [23, 24].

In order to study the interactions of hydrogen with steel, the purpose of this research is to analyze hydrogen diffusion and trapping processes through a quenched and tempered high strength low alloy steel (HSLA) within an acid media by varying charging conditions and temperature. Many investigations have been carried out on industrial steels but the originality of this work consists in studying a model material whose properties are close to real industrial steel and where the chemical composition, the microstructure and the heterogeneousness are thoroughly investigated and related to the electrochemical data. Thus, the geometrical characteristic of the presumed traps present in the model material may be evaluated. 


\section{Experimental}

\subsection{Materials}

An electrochemical permeation technique was used to study the hydrogen diffusion and trapping in a Fe$0.45 \%$ wt C-1.5\%wt Mo quenched and tempered martensitic steel. The material was electro eroded to obtain disks of $25 \mathrm{~mm}$ diameter and of $1.2 \mathrm{~mm}$ initial thickness. Samples were ground with $\mathrm{SiC}$ grinding paper down to 4000 grit then ultrasonically cleaned in acetone and rinsed with distilled water. The final thickness is about $1.1 \mathrm{~mm}$ and the exposed area is $3.14 \mathrm{~cm}^{2}(\varnothing=2 \mathrm{~cm})$.

\subsection{Microstructural characterization}

Different scales of heterogeneousness describing the tempered martensitic microstructure were investigated by a Leica DM6000M optical microscope, by scanning electron microscopy (SEM Philips FEI, Quanta 200FEG/ESEM, 20kV) associated with electron back scattering diffraction (EBSD) and by transmission electron microscopy (TEM JOEL 2010 200kV). For optical observations, the microstructure is revealed by a chemical attack using a nital solution $(98 \mathrm{~mL}$ methanol $+2 \mathrm{~mL}$ nitric acid) during few seconds. EBSD (Electron Back Scattered Diffraction) and TEM (Transmission Electron Microscopy) analyses were performed on very thin samples $(80 / 90 \mu \mathrm{m})$ in order to minimize the effect of magnetism of the sample with the electron beam. They were electro polished with a perchloric acid (5\%), glycerol $(20 \%)$ and methanol solution at $243 \mathrm{~K}, \mathrm{E}=28 \mathrm{~V}$ during approximatively 2 minutes. They were then rinsed with ethanol and dried at room temperature with an appropriate cloth. TSL OIM ${ }^{\circledR}$ Analyses 5 software was used for the orientation measurements and analysis. Carbides were characterized by TEM by using X-ray spectroscopy (EDAX) and by X-ray diffraction to determine the crystallographic structure. The exact chemical composition of the precipitates is difficult to quantify by EDX, essentially carbon which is a light element. That is why only one alloying element (molybdenum) is reported in the present work.

\subsection{Electrochemical permeation test}

The instrumentation of electrochemical hydrogen permeation was composed of an electrolytic cell with two compartments. Both compartments are equipped of one saturated sulfate reference electrode SSE $\left(\mathrm{Hg} / \mathrm{Hg}_{2} \mathrm{SO}_{4} / \mathrm{K}_{2} \mathrm{SO}_{4}\right)$, one platinum auxiliary electrode, a floating ground galvanostat PGP201 for the charging side and a potentiostat Autolab PGSTAT302N for the detection side. Deionized water was circulated in the double jacket through a cryothermostat LAUDA in order to maintain a constant temperature. The temperature was varied in the range of 283 to $313 \mathrm{~K} \pm 0.5 \mathrm{~K}$. Solutions in both cells were continuously deoxygenated by argon. The cathodic side of the specimen was galvanostatically polarized at a constant charging current density in the range of $5-200 \mathrm{~mA} / \mathrm{cm}^{2}$ in $1 \mathrm{M} \mathrm{H}_{2} \mathrm{SO}_{4}(\mathrm{pH}=0.18)$. The electrochemical reactions occurring on the steel surface during cathodic polarization (Figure 1a) correspond to the Hydrogen Evolution Reaction [25] composed of an initial Volmer electrochemical adsorption and electrochemical or chemical desorption at a much higher cathodic polarization (Heyrovsky and Tafel reactions). These points are important to distinguish in further work the effect of electrochemical adsorption and the competition between adsorption/desorption with a $\mathrm{H}_{2}$ 
recombination at higher charging current densities. A part of the adsorbed hydrogen is then absorbed and diffuses through the steel membrane. On the detection side, the sample was potentiostatically maintained at a constant potential of $-358 \mathrm{mV} / \mathrm{Hg} / \mathrm{HgO}$ in $0.1 \mathrm{M} \mathrm{NaOH}(\mathrm{pH}=12.6)$ (Figure 1b). This potential was sufficient to oxidize the hydrogen atoms emerging on the output face. The anodic current gives a direct measure of the hydrogen flow rate. The detection side is previously maintained at this potential during $80000 \mathrm{~s}$ in order to stabilize the anodic current for approximately $0.1 \mu \mathrm{A} \cdot \mathrm{cm}^{-2}$. The principal and the experimental setup of the electrochemical permeation test are shown on Figure 2.

Figure 1: Polarization curves in $1 \mathrm{M} \mathrm{H}_{2} \mathrm{SO}_{4}$ (a) and in $0.1 \mathrm{M} \mathrm{NaOH}$ (b) on Fe-C-Mo samples at $293 \mathrm{~K}$ and $\mathrm{S}=1 \mathrm{~cm}^{2}$

Figure 2: Scheme and device of the electrochemical permeation test

\section{Permeation analyses and interpretation}

\subsection{Diffusion laws}

In the classical permeation technique introduced by Devanathan and Stachursky [23], a thin metal membrane of thickness L is placed between two independent electrochemical cells. Hydrogen is introduced on the entry side $(\mathrm{x}=0)$, diffuses through the membrane and is immediately oxidized on the exit side $(\mathrm{x}=\mathrm{L})$. The convenience of permeation techniques is based on the assumption that the conditions of diffusion are established beneath the entry side, where the concentration of hydrogen $C_{0}$ is supposed to be constant. The main problem consists in the presence of a passive layer on the exit side. The stability of the oxide layer may control the diffusion phenomenon and can have consequences on the experimental results $[6,9,26]$. This can be clearly demonstrated by using finite element methods for the diffusion modeling [27]. That is to say that diffusion curves correspond to a multilayered system with two different materials and their own diffusion coefficient $\mathrm{D}$. Thus, only an apparent diffusion coefficient $\mathrm{D}_{\text {app }}$ can be determined, if we consider the system (steel + oxide layer) as a homogeneous representative volume element (HRVE). Fick's laws (1) (2) describe diffusion into the multilayered system assuming that diffusion is unidirectional:

$j(x, t)=-D_{a p p} \cdot \frac{\partial C(x, t)}{\partial x}$

$\frac{\partial \mathrm{C}}{\partial \mathrm{t}}=\mathrm{D}_{\mathrm{app}} \cdot \frac{\partial^{2} \mathrm{C}}{\partial \mathrm{x}^{2}}$

In the case that the hydrogen subsurface concentration is supposed to be constant [23], the diffusion process can be determined by equation (3).

$\frac{\mathrm{j}}{\mathrm{j}_{\infty}}=\frac{2}{\sqrt{\pi \tau}} \sum_{\mathrm{n}=0}^{\infty} \exp \left(-\frac{(2 \mathrm{n}+1)^{2}}{4 \tau}\right)=1+2 \sum_{\mathrm{n}=1}^{\infty}(-1)^{\mathrm{n}} \exp \left(-\mathrm{n}^{2} \pi^{2} \tau\right)$ 
Two analytical solutions (4) and (5) of Fick's laws are employed to model the diffusion phenomenon when the hydrogen concentration is supposed to be constant beneath the entry side $\mathrm{C}=\mathrm{C}_{0}$ and equal to zero on the exit side $\mathrm{C}=0$.

$\mathrm{j}=\mathrm{j}_{\infty} \frac{2}{\sqrt{\pi \tau}} \exp \left(-\frac{1}{4 \tau}\right) \quad$ with $\tau=\mathrm{D}_{\text {app }} . \mathrm{t} / \mathrm{L}^{2}<0,3$

$\mathrm{j}=\mathrm{j}_{\infty}\left(1-2 \exp \left(-\pi^{2} \tau\right)\right) \quad$ with $\tau=\mathrm{D}_{\text {app }} \cdot \mathrm{t} / \mathrm{L}^{2}>0,2$

where $\mathrm{j}$ is the measured permeation rate versus time, $\mathrm{j}_{\infty}$ the steady-state permeation rate, $\mathrm{t}$ the time $(\mathrm{s}), \mathrm{L}$ the thickness of the membrane $(\mathrm{m})$ and $\mathrm{D}_{\text {app }}$ the apparent diffusion coefficient $\left(\mathrm{m}^{2} / \mathrm{s}\right)$.

\subsection{Data analysis: diffusible hydrogen}

The hydrogen apparent diffusion coefficient can be calculated with the mathematical relation derived from Fick's solutions for the appropriate boundary conditions:

$\mathrm{D}_{\mathrm{app}}=\frac{\mathrm{L}^{2}}{\mathrm{M} . \mathrm{t}}$

where $\mathrm{L}$ is the sample thickness and $\mathrm{M}$ a constant depending on the time value $\mathrm{t}$ chosen in the diffusion transient $\left(\mathrm{M}=25\right.$ for $1 \% \mathrm{j}_{\infty}, \mathrm{M}=15.3$ for $10 \% \mathrm{j}_{\infty}, \mathrm{M}=6$ for $63 \% \mathrm{j}_{\infty}$ ) (Figures $3 \mathrm{a}$ and $3 \mathrm{~b}$ ). $\mathrm{D}_{\text {app }}$ is generally defined by a steady-state current density $j_{\infty}$ which imposed a value of time. Nevertheless, in the hydrogen permeation rate measurements available in literature, the breakthrough time is not clearly defined: the more widely used is a time value which corresponds to $10 \%$ of $\mathrm{J}_{\infty}$. In this way, $\mathrm{M}=15.3$. The intersection of the tangent at the inflection point of the permeation rate-time curve with the initial permeation level leads to $M=19.8$. The constant $M$ evolves quickly according to the time to attain chosen fraction of the steady state permeation rate $(\mathrm{M}=25$ for $1 \% \mathrm{j}_{\infty}, 35$ for $0.1 \% \mathrm{j}_{\infty}$ ). Consequently, we decided to define criterion to clearly distinguish each technique. Another technique has been developed in order to evaluate the apparent diffusion coefficient without taking into account $\mathrm{j}_{\infty}$ (which can be affected by a surface evolution or the trapping process during the first permeation transient). The "Regime 1 technique" allows to verify is the apparent diffusion coefficient is coherent with the apparent diffusion coefficient calculated with the others methods. This methodology is based on the beginning of the transient and is related with the equation (4) (Figure 3a). A mathematical approach allows to obtain a simple equation depending on time, on the thickness of the membrane and on the apparent diffusion coefficient. The experimental requirement is based on a good reproducibility of the experimental results. The numerical adjustment of the experimental curve with the theoretical " $1{ }^{\text {st }}$ Regime" described in equation (7) gives a value of the apparent diffusion coefficient (Figure 3c).

$\frac{\partial \ln (\mathrm{j})}{\partial \mathrm{t}}=-\frac{1}{2 \mathrm{t}}+\frac{\mathrm{L}^{2}}{4 \mathrm{D}_{\mathrm{app}} \mathrm{t}^{2}}$

The apparent diffusion coefficient can depend on trapping processes and can also depend on the evolution of the surface state $[26,27]$. The correlation between the method at $10 \%$ of the steady state current and the "Regime 1 " 
methods as function of the apparent diffusion coefficient obtained by the method at $1 \%$ of the steady state current (Figure 3d) shows a slop close to 1 . Whatever the technique used, the value of the apparent diffusion coefficient is quite the same. Thus, the evolution of sample surfaces or the trapping processes can be negligible for the determination of the apparent diffusion coefficient.

Figure 3: Experimental (a, b) and adjusted experimental data (c) for the Fe-C-Mo model steel under a $20 \mathrm{~mA} / \mathrm{cm}^{2}$ cathodic polarization in $1 \mathrm{M} \mathrm{H}_{2} \mathrm{SO}_{4}$ at $293 \mathrm{~K}$ and the correlation (d) between the different methods of determination of the apparent diffusion coefficient as function of the apparent diffusion coefficient obtained by the method at $1 \%$ of the steady state current.

If the charging surface is in equilibrium, the apparent subsurface concentration $\mathrm{C}_{0 \mathrm{app}}(\mathrm{ppm} \mathrm{wt})$ can be determined by:

$\mathrm{C}_{0 \text { app }}=\frac{\mathrm{j}_{\infty} * \mathrm{~L}}{\mathrm{~F} \cdot \mathrm{D}_{\mathrm{app}}} \cdot \frac{\mathrm{M}_{\mathrm{H}}}{\rho_{\mathrm{Fe}}} \cdot 10^{6}$

where $\mathrm{j}_{\infty}$ is the steady-state permeation rate $\left(A / \mathrm{m}^{2}\right), \mathrm{L}$ the thickness of the membrane $(\mathrm{m}), \mathrm{D}_{\text {app }}$ the apparent diffusion coefficient $\left(\mathrm{m}^{2} / \mathrm{s}\right), \mathrm{F}$ the Faraday constant $(96485 \mathrm{C} / \mathrm{mol}), \mathrm{M}_{\mathrm{H}}$ the molar mass of hydrogen $(1 \mathrm{~g} / \mathrm{mol})$ and $\rho_{\mathrm{Fe}}$ the iron density $\left(7.87 \times 10^{6} \mathrm{~g} / \mathrm{m}^{3}\right)$.

\subsection{Data analysis: trapped hydrogen}

The complete decay is sensitive to hydrogen release. It can be used to determine the quantity of the lattice hydrogen and the reversible trapped hydrogen [28]. Figure 4 shows the experimental desorption rate on the exit side and the theoretical curve using equation (9) [24]. The theoretical curve is representative of the transport of hydrogen atoms where the membrane is supposed to be free of trap sites. Moreover, the total decay reflects the release of lattice hydrogen $C_{L}$ and reversible trapped hydrogen $C_{T r}$. Thus, the total desorption rate is the sum of the desorption rates of the lattice hydrogen $C_{L}$ and the reversible trapped hydrogen $C_{T r}$.

$\mathrm{j}=\mathrm{j}_{\infty}\left(1-\frac{2 \mathrm{~L}}{\sqrt{\pi \mathrm{D}_{\mathrm{app}}}} \sum_{\mathrm{n}=0}^{\infty} \exp \left(-\frac{(2 \mathrm{n}+1)^{2} \mathrm{~L}^{2}}{4 \mathrm{D}_{\mathrm{app}} \mathrm{t}}\right)\right)$

Figure 4: Analysis of the hydrogen desorption from the Fe-C-Mo model steel on the exit side after a $-20 \mathrm{~mA} / \mathrm{cm}^{2}$ cathodic polarization in $1 \mathrm{M} \mathrm{H}_{2} \mathrm{SO}_{4}$ at $293 \mathrm{~K}$

The area defined between theoretical and experimental curves corresponds to the amount of reversible trapped hydrogen $\mathrm{C}_{\mathrm{Tr}}$. This area, in $\mu \mathrm{A} . \mathrm{s} / \mathrm{cm}^{2}$, can be expressed in ppm wt according to the equation (10):

$\mathrm{C}_{\mathrm{H}}=\quad \cdot \frac{\mathrm{M}_{\mathrm{H}}}{\text { F.L. } \rho_{\mathrm{Fe}}}$ 
where $\mathrm{L}$ is the thickness of the membrane $(\mathrm{cm}), \mathrm{F}$ the Faraday constant $(96485 \mathrm{C} / \mathrm{mol}), \mathrm{M}_{\mathrm{H}}$ the molar mass of hydrogen $(1 \mathrm{~g} / \mathrm{mol})$ and $\rho_{\mathrm{Fe}}$ the iron density $\left(7.87 \mathrm{~g} / \mathrm{cm}^{3}\right)$.

Finally, it is possible to estimate the amount of the irreversible trapped hydrogen $\mathrm{C}_{\mathrm{Tir}}$ using the basic equation (11) by supposing that, in the case of an oxide layer on the exit surface, the average concentration in the membrane is quite homogenous and close to $\left\langle\mathrm{C}>\approx \mathrm{C}_{0 \text { app }}\right.$. The fact that the oxide layer acts like a barrier to the hydrogen diffusion has already been verified in other studies, where the concentration at the interface metal/oxide is not equal to zero but converges to the entry subsurface concentration [26].

$\mathrm{C}_{\mathrm{Tir}}=<\mathrm{C}>-\mathrm{C}_{\mathrm{L}}-\mathrm{C}_{\mathrm{Tr}}$

\section{Results}

\subsection{Fe-C-Mo microstructure characterization}

Microstructural characterizations allow to determine the segregation zones at different scales, from the grain interface to the dislocation density. The martensitic microstructure can be schematized by a multiple of interfaces as it is represented on Figure 5. Microstructural observations show that the martensite transformation subdivides a prior austenite grain on four different scales into packets, blocks, sub-blocks and lathes [29]. Microstructural analyses (Figure 6) show a tempered martensite with traces of retained austenite at the lath/lath interface and different characteristics of the material as the lathes dimensions, the precipitate density and the dislocation density can be determined (table 1). Grains in this polycristal are oriented randomly. As a consequence, a wide range of different grain boundaries exists. The nature of a grain boundary depends on the misorientation of two adjoining grains. The misorientation can reach $45^{\circ}$ as the EBSD micrograph demonstrates on the Figure 6b. Moreover the HSLA steel contains only one alloying element which can form various types of precipitate as it is presented on Figure 7. In this study, two types of precipitates have been found by using X-ray diffraction and EDS analyses, both techniques coupled to TEM. Based on previous works [30], two types of precipitate were characterized: cubic carbide $\tau\left(\mathrm{ex}: \mathrm{Fe}_{21} \mathrm{Mo}_{2} \mathrm{C}_{6}\right)$ with a diameter ranging from 100 to $160 \mathrm{~nm}$ and a low molybdenum content and orthorhombic carbide $\xi\left(\mathrm{ex}: \mathrm{Fe}_{2} \mathrm{MoC}\right)$ or/and cubic carbide $\eta\left(\mathrm{ex}: \mathrm{M}_{6} \mathrm{C}\right)$ with a diameter less than $80 \mathrm{~nm}$ and a composition of molybdenum between 20-60\%wt. Microstructural characterizations presented in table 1 permit to list different scales of potential trap sites: macroscopic sites (prior $\gamma$ grain boundaries, martensitic lathes), precipitates (precipitate density, nature) and dislocations (dislocation density, elastic field).

Figure 5: Microstructural hierarchy of a martensitic microstructure [29]

Figure 6: Optical (a), EBSD (b) and TEM micrographs (c,d) of the specimen

Table 1: Microstructural characterization of the Fe-C-Mo HSLA martensitic steel

Figure 7: Inter lathes precipitation characterizations by TEM and XRD: 
a - Cubic carbide $\tau$ (ex: $\left.\mathrm{Fe}_{21} \mathrm{Mo}_{2} \mathrm{C}_{6}\right)$

$\mathrm{b}-$ Orthorhombic carbide $\xi\left(\mathrm{ex}: \mathrm{Fe}_{2} \mathrm{MoC}\right)$ or/and cubic carbide $\eta\left(\mathrm{ex}: \mathrm{M}_{6} \mathrm{C}\right)$

\subsection{Influence of charging conditions on diffusivity}

Electrochemical permeation tests had been done at $293 \mathrm{~K}$ in order to determine the apparent diffusion coefficient $\mathrm{D}_{\text {app }}$ and the hydrogen apparent concentration on the subsurface $\mathrm{C}_{0 \mathrm{app}} \approx<\mathrm{C}>$. Different charging conditions (from $5 \mathrm{~mA} / \mathrm{cm}^{2}$ to $200 \mathrm{~mA} / \mathrm{cm}^{2}$ ) were tested to obtain a variation of $\langle\mathrm{C}>$. Figure 8 shows the influence of six charging conditions on the permeation curves. As it is classically reported in the literature [12,31], the breakthrough time is decreasing and the steady-state current is increasing (Figure 8a, table 2). Moreover, kinetics of diffusion are accelerated under high charging conditions (Figure $8 \mathrm{~b}$ ).

Figure 8: Permeation transient $\mathrm{j}=\mathrm{f}(\mathrm{t})$ (a) and the experimental " $1{ }^{\text {st }}$ Regime" $\frac{\partial \ln (\mathrm{J})}{\partial \mathrm{t}}=\mathrm{f}(\mathrm{t})$ (b) for the Fe-C-Mo steel membrane under cathodic polarization in $1 \mathrm{M} \mathrm{H}_{2} \mathrm{SO}_{4}$ at $293 \mathrm{~K}$

Table 2: Hydrogen permeation results in Fe-C-Mo steel under cathodic polarization in $1 \mathrm{M} \mathrm{H}_{2} \mathrm{SO}_{4}$ at $293 \mathrm{~K}$

The plot of $\mathrm{D}_{\text {app }}$ as a function of $<\mathrm{C}>$ (Figure 9) presents two domains with a maximum value of $7.4 \times 10^{-11} \mathrm{~m}^{2} / \mathrm{s}$ for a subsurface concentration of about $0.4 \mathrm{ppm}$ wt. The increase of $\mathrm{D}_{\text {app }}$ may be linked to a competition between two kinetic processes: the hydrogen trapping and diffusion (domain I). When all trapping sites are filled, only lattice diffusion may occur i.e. the saturation curve corresponds to the hydrogen diffusion coefficient $\mathrm{D}$ in the metal (domain II). These measures seem to be in accordance with the apparent diffusion coefficient obtained in the literature where $D_{\text {app }}$ is included between $10^{-12}[32,33]$ and $10^{-9} \mathrm{~m}^{2} / \mathrm{s}[34]$ for HSLA steels. Moreover, the increase of $D_{\text {app }}$ as a function of $<C>$ has been obtained by several authors $[35,36]$ for materials where the influence of grain boundaries and microstructure on diffusion and trapping were predominant. Consequently, hydrogen diffusion cannot be discussed without considering trapping processes.

Figure 9: Apparent diffusion coefficient in the Fe-C-Mo HSLA steel as a function of the apparent subsurface concentration of hydrogen at $293 \mathrm{~K}$

\subsection{Influence of charging conditions on trapping processes}

The complete decay of the desorption step (Figure 4) is sensitive to hydrogen release. The evolution of the quantity of hydrogen as a function of the apparent subsurface concentration is shown on Figure 10. The amounts of lattice hydrogen and irreversible trapped hydrogen increase linearly with the solubility $<\mathrm{C}>$ whatever the domain, whereas the amount of reversible trapped hydrogen raises in domain I and reaches a constant value in domain II. The ratios of each hydrogen types tend to a constant value in domain II: $78 \%$ for irreversible trapped hydrogen, $18 \%$ for reversible trapped hydrogen and 4\% for lattice hydrogen. Zakrowzymski [28] obtained $\mathrm{qHd} \approx 2.4 \%$ and $\mathrm{qHr}+\mathrm{qHir} \approx 97.6 \%$ for a pure Armco iron membrane in $0.1 \mathrm{M} \mathrm{NaOH}$ under $-10 \mathrm{~mA} / \mathrm{cm}^{2}$ at $298 \mathrm{~K}$. These results demonstrate that the solubility of hydrogen into the material is controlled by the amount of trapped hydrogen which can reach $96 \%$ in the range of the hydrogen working concentrations. According to the previous 
results (Figure 9), the increase of irreversible and reversible trapped hydrogen may be linked to the storage of hydrogen on trapping sites and seems to have influence on the evolution of diffusion processes in both domains (Figure 10).

Figure 10: Evolution of irreversible, reversible trapped and lattice hydrogen as a function of the apparent subsurface concentration of hydrogen under cathodic polarization at $293 \mathrm{~K}$

Oriani [37] and Krom [38] defined the apparent diffusion coefficient as:

$\mathrm{D}_{\mathrm{app}}=\frac{\mathrm{D}_{\mathrm{L}}}{1+\partial \mathrm{C}_{\mathrm{T}} / \partial \mathrm{C}_{\mathrm{L}}}$

where $D_{L}$ is the lattice diffusion coefficient, $C_{T}$ is the hydrogen concentration in trap sites and $C_{L}$ is the hydrogen concentration in lattice sites. $C_{T}$ is equal to $C_{T i r}+C_{T r}$ where $C_{T i r}$ is the hydrogen concentration in irreversible traps and $\mathrm{C}_{\mathrm{Tr}}$ is the hydrogen concentration in reversible traps. According to the previous results (Figure 10a), a phenomenological approach is done and leads to expressions of $\mathrm{C}_{\mathrm{L}}, \mathrm{C}_{\mathrm{Tir}}$ and $\mathrm{C}_{\mathrm{Tr}}$ :

$\mathrm{C}_{\mathrm{L}}=\mathrm{A}_{\mathrm{L}} \cdot<\mathrm{C}>$

$\mathrm{C}_{\text {Tir }}=\mathrm{A}_{\text {Tir }} \cdot\langle\mathrm{C}>$

$\mathrm{C}_{\mathrm{Tr}}=\mathrm{B}_{\mathrm{Tr}} \cdot\left[1-\exp \left(-\mathrm{b}_{\mathrm{Tr}}\left(<\mathrm{C}>-\mathrm{C}_{0 \mathrm{~T}}\right)\right)\right]$

where $A_{L}, A_{T i r}, B_{T r}, b_{T r}$ are constants and $C_{0 T}$ is supposed to be the residual hydrogen concentration into the membrane before an entry of hydrogen. The derivatives of the irreversible and reversible hydrogen concentrations can be written as:

$$
\begin{aligned}
& \frac{\partial \mathrm{C}_{\mathrm{L}}}{\partial<C>}=\mathrm{A}_{\mathrm{L}} \\
& \frac{\partial \mathrm{C}_{\mathrm{Tir}}}{\partial<C>}=\mathrm{A}_{\mathrm{Tir}} \\
& \frac{\partial \mathrm{C}_{\mathrm{Tr}}}{\partial<C>}=\mathrm{B}_{\mathrm{Tr}} \cdot \mathrm{b}_{\mathrm{Tr}} \cdot \exp \left[-\mathrm{b}_{\operatorname{Tr}}\left(<\mathrm{C}>-\mathrm{C}_{0 \mathrm{~T}}\right)\right]
\end{aligned}
$$

Finally, the derivative of the total trapped hydrogen concentration $\mathrm{C}_{\mathrm{T}}$ is given by:

$$
\frac{\partial \mathrm{C}_{\mathrm{T}}}{\partial<C>}=\frac{\partial \mathrm{C}_{\mathrm{Tir}}}{\partial<C>}+\frac{\partial \mathrm{C}_{\mathrm{Tr}}}{\partial<C>}=\mathrm{A}_{\mathrm{Tir}}+\mathrm{B}_{\mathrm{Tr}} \cdot \mathrm{b}_{\mathrm{Tr}} \cdot \exp \left[-\mathrm{b}_{\mathrm{Tr}}\left(<\mathrm{C}>-\mathrm{C}_{0 \mathrm{~T}}\right)\right]
$$

In our case, $\mathrm{A}_{\mathrm{L}}=0.0395, \mathrm{~A}_{\text {Tir }}=0.7465$ and the adjustment of the equation (15) with the experimental data, relative to the evolution of the reversible trapped hydrogen as a function of $<\mathrm{C}>$, gives $\mathrm{B}_{\mathrm{Tr}}=0.13, \mathrm{~b}_{\mathrm{Tr}}=8, \mathrm{C}_{0 \mathrm{~T}}=0.075 \mathrm{ppm}$ wt. According to equations (12) and (19), it is possible to determine a model able to adjust experimental data relative to the evolution of the apparent diffusion coefficient as a function of the hydrogen subsurface concentration (Figure 9). The modeling of experimental data leads to a value of $\mathrm{D}_{\mathrm{L}}=1.45 \times 10^{-9} \mathrm{~m}^{2} / \mathrm{s}$ which is slightly lower than the values of the lattice diffusivity of hydrogen in pure iron $\left(\mathrm{D}_{\mathrm{Fe} \alpha} \approx 10^{-8}\right.$ to $\left.10^{-9} \mathrm{~m}^{2} / \mathrm{s}\right)[8,34,39$, 40], which suggests an effect of solute atoms ( $\mathrm{C}$ and Mo). The decrease in hydrogen diffusivity due to the 
increase of carbon content has been previously reported [41]. The evolution of the partial derivatives of the hydrogen concentration in trap sites $C_{T}$ with respect to the hydrogen concentration in lattice $C_{L}$ sites (Figure 11a) and the diagram of predominance (Figure 11b) supposed that the apparent diffusion coefficient is mainly controlled by both reversible and irreversible trapped hydrogen in the domain I whereas it is controlled by the amount of irreversible trapped hydrogen in the domain II. Moreover, domain I can be separated in two subdomains where the contribution of reversible trapped hydrogen is higher when $<\mathrm{C}>\leq 0.12 \mathrm{ppm}$ wt.

Figure 11: Evolution of the partial derivatives of the hydrogen concentration in trap sites $\mathrm{C}_{\mathrm{T}}$ with respect to the hydrogen concentration in lattice $\mathrm{C}_{\mathrm{L}}$ sites (a) and evolution of the partial derivatives of the hydrogen concentration in trap sites $\mathrm{C}_{\mathrm{Ti}}$ with respect to the total hydrogen concentration in traps sites $\mathrm{C}_{\mathrm{T}}(\mathrm{b})$ in the Fe-CMo HSLA steel cathodic polarization at $293 \mathrm{~K}$

\subsection{Influence of temperature on diffusion processes}

Electrochemical permeation tests were done at different temperatures (from 283 to $313 \mathrm{~K}$ ) in order to access the activation energy of hydrogen diffusion processes. Figure 12a exhibits the influence of the temperature on the permeation curves. As it is classically reported in the literature, the breakthrough time decreases while the steady-state current increases [42]. Table 3 displays the results of hydrogen permeation in Fe-C-Mo steel at four working temperatures. Values of $\mathrm{D}_{\text {app }}$ reveal an acceleration of diffusivity with the raise of temperature. However, the variation of $<\mathrm{C}>$ calculated from equation (8) shows that it relies on the charging conditions, temperature and some more parameters. It has already been reported that an oxide layer formed on the exit side of the membrane has a real influence on solubility $[6,7,27]$ according to its diffusion coefficient, which can vary from $10^{-16}[43]$ to $10^{-21} \mathrm{~m}^{2} / \mathrm{s}[44]$.

Figure 12: Permeation transient $\mathrm{j}=\mathrm{f}(\mathrm{t})(\mathrm{a})$ and the experimental " $1^{\text {st }}$ Regime" $\frac{\partial \ln (\mathrm{J})}{\partial \mathrm{t}}=\mathrm{f}(\mathrm{t})(\mathrm{b})$ for the Fe-C-Mo steel membrane under $-20 \mathrm{~mA} / \mathrm{cm}^{2}$ cathodic polarization in $1 \mathrm{M} \mathrm{H}_{2} \mathrm{SO}_{4}$ at $283,293,303$ and $313 \mathrm{~K}$

Table 3: Hydrogen permeation results in Fe-C-Mo steel under $-20 \mathrm{~mA} / \mathrm{cm}^{2}$ cathodic polarization in $1 \mathrm{M} \mathrm{H}_{2} \mathrm{SO}_{4}$ at $283,293,303$ and $313 \mathrm{~K}$

Under the same charging conditions, the apparent diffusion coefficient $\mathrm{D}_{\text {app }}$ and the interstitial diffusion coefficient $\mathrm{D}_{\mathrm{L}}$ varies with temperature i.e. it is a thermically activated process. Thus it can be expressed by an Arrhenius relationship:

$D_{\text {app }}=D_{0 a p p} \cdot \exp \cdot\left(-\frac{E_{D}}{k_{b} \cdot T}\right)$

and

$D_{L}=D_{0} \cdot \exp \cdot\left(-\frac{E_{D}}{k_{b} \cdot T}\right)$

where $\mathrm{D}_{0 \text { app }}$ and $\mathrm{D}_{0}$ are the pre-exponential factors relative to the probability of mobility of hydrogen [45], $\mathrm{E}_{\mathrm{D}}$ is the activation energy of diffusion process and $\mathrm{k}_{\mathrm{b}}$ is the Boltzmann constant $\left(8.62 .10^{-5} \mathrm{eV} / \mathrm{K}\right)$. Figure 13 exposes 
$\ln \mathrm{D}_{\text {app }}$ vs $1 / \mathrm{T}$ and a linear regression which leads to $\mathrm{D}_{0 \mathrm{app}}=1.25 \times 10^{-6} \mathrm{~m}^{2} / \mathrm{s}$ and an activation energy of diffusion process $\mathrm{E}_{\mathrm{D}}=0.26 \mathrm{eV}$. $\mathrm{D}_{0 \text { app }}$ has been noted to fluctuate from $\mathrm{D}_{0 \text { app }}=1.02 \times 10^{-10} \mathrm{~m}^{2} / \mathrm{s}$ for pure Armco iron [42] to $\mathrm{D}_{0 \text { app }}=1.33 \times 10^{-6} \mathrm{~m}^{2} / \mathrm{s}$ for quenched martensite [46]. The activation energy of diffusion process has been reported to vary from $\mathrm{E}_{\mathrm{D}}=0.20 \mathrm{eV}$ for pure Armco iron [42] to $\mathrm{E}_{\mathrm{D}}=0.36 \mathrm{eV}$ for quenched martensite [46], or $\mathrm{E}_{\mathrm{D}}=0.35 \mathrm{eV}$ for quenched and tempered martensite [47]. A dependence of the activation energy with the microstructure is clearly demonstrated. The pre-exponential factor $\mathrm{D}_{0 \text { app }}$ is changes with the microstructure and so depends on the mean free path of hydrogen into materials. Using equations (20) and (21), it is possible to evaluate real intrinsic value of $\mathrm{D}_{0}$ :

$\mathrm{D}_{0}=\frac{\mathrm{D}_{0 \mathrm{app}} \times \mathrm{D}_{\mathrm{L}\left(20^{\circ} \mathrm{C}\right)}}{\mathrm{D}_{\mathrm{app}}\left(20^{\circ} \mathrm{C}\right)}$

with $\mathrm{D}_{0 \mathrm{app}}=1.25 \times 10^{-6} \mathrm{~m}^{2} / \mathrm{s}, \mathrm{D}_{\mathrm{L}\left(20^{\circ} \mathrm{C}\right)}=1.45 \times 10^{-9} \mathrm{~m}^{2} / \mathrm{s}$ and $\mathrm{D}_{\text {app }\left(20^{\circ} \mathrm{C}\right)}=4.94 \times 10^{-11} \mathrm{~m}^{2} / \mathrm{s}$. This leads to $\mathrm{D}_{0}=3.68 \times 10^{-5} \mathrm{~m}^{2} / \mathrm{s}$.

Figure 13: Evolution of the apparent and lattice diffusion coefficients in Fe-C-Mo steel as a function of reciprocal temperature adjusted with an Arrhenius law under $-20 \mathrm{~mA} / \mathrm{cm}^{2}$ cathodic polarization in $1 \mathrm{M} \mathrm{H}_{2} \mathrm{SO}_{4}$

The effect of temperature allows to determine the number of trap sites $\mathrm{N}_{\mathrm{T}}$ per unit volume by using the Kumnick and Johnson method [48]. Based on the McNabb-Foster formalism [49], it is the most direct way to analyze trapping data. In this approach, the hydrogen concentration at the input surface of the permeation membrane is related to the "breakthrough time" with trapping:

$\frac{\mathrm{t}_{\mathrm{T}}}{\mathrm{t}_{\mathrm{L}}}-1=\frac{3 \mathrm{~N}_{\mathrm{T}}}{<\mathrm{C}>}$

where $t_{L}$ is the purely lattice "breakthrough time" given by $t_{L}=\frac{L^{2}}{M \cdot D_{L}}, t_{T}$ is the "breakthrough time" with trapping, $\mathrm{N}_{\mathrm{T}}$ is the number of trapping sites per unit volume and $<\mathrm{C}>$ is the average hydrogen concentration. Figure 14 represents the evolution of $\mathrm{t}_{\mathrm{T}} / \mathrm{t}_{\mathrm{L}}-1$ as a function of reciprocal hydrogen concentration which permits to evaluate $\mathrm{N}_{\mathrm{T}} \approx 1.27 \times 10^{25} \mathrm{~m}^{-3}$. In $\alpha$-iron, $\mathrm{N}_{\mathrm{T}}$ associated with dislocations is varying from $8.5 \times 10^{20}$ to $1.8 \times 10^{23} \mathrm{~m}^{-3}$ for 0 to $80 \%$ of tensile plastic strain [48] which is lower than our measurement. Considering these values, incidental dislocations cannot be the only trapping sites in our alloy, which suggests that geometrical necessary dislocations localized in inter-lathes play also a role in the trapping process.

Figure 14: Evolution of $t_{\mathrm{T}} / \mathrm{t}_{\mathrm{L}}-1$ as a function of reciprocal hydrogen concentration for the Fe-C-Mo steel membrane under cathodic polarization in $1 \mathrm{M} \mathrm{H}_{2} \mathrm{SO}_{4}$ at $293 \mathrm{~K}$

\subsection{Influence of temperature on trapping processes}

According to theorical models [37,38], trapping is a thermically activated process. Figure 15 describes the evolution of trapped hydrogen and interstitial hydrogen as function of temperature. A weak increase of interstitial hydrogen is observed when trapped hydrogen decreases. This infers that the augmentation of temperature supplies enough energy to hydrogen enabling it to escape from traps and then induces acceleration of diffusion. 
Figure 15: Evolution of diffusible and total trapped hydrogen (a) and irreversible/reversible trapped hydrogen (b) as a function of temperature in $1 \mathrm{M} \mathrm{H}_{2} \mathrm{SO}_{4}$ under $-20 \mathrm{~mA} / \mathrm{cm}^{2}$ cathodic polarization

Figure 16 is a schematic view of energy relations in hydrogen-metal system: $\Delta \mathrm{E}_{\mathrm{L}}$ is the activation energy for moving from a lattice site to an adjacent lattice site and $\Delta \mathrm{E}_{\mathrm{TL}}$ is the trap energy for moving from a lattice site to a trapping site.

Figure 16: Schematic view of energy relations in hydrogen-metal system

The mobility of dissolved hydrogen in the iron lattice, with an amount of trapping sites, can be analyzed using Oriani [37] and Krom [38] trap models. Considering equilibrium between diffusible and trapped hydrogen, the trap binding energy $\Delta \mathrm{E}_{\mathrm{T}}$ can be determined using the equations (25) and (26).

$\frac{1}{\theta_{\mathrm{L}}}\left(\frac{\theta_{\mathrm{T}}}{1-\theta_{\mathrm{T}}}\right)=\exp \left(-\frac{\Delta \mathrm{E}_{\mathrm{T}}}{\mathrm{k}_{\mathrm{B}} \mathrm{T}}\right) \quad$ where $\quad \Delta \mathrm{E}_{\mathrm{T}}=\Delta \mathrm{E}_{\mathrm{TL}^{-}}-\mathrm{E}_{\mathrm{D}}$

where $\theta_{\mathrm{L}}$ is the occupancy of lattice sites: $\theta_{\mathrm{L}}=\mathrm{C}_{\mathrm{L}} / \mathrm{N}_{\mathrm{L}}$ with $\mathrm{N}_{\mathrm{L}}=5.1 \times 10^{29} \mathrm{~m}^{-3}$ [38] the number of lattice sites per unit volume, $\theta_{\mathrm{T}}$ is the occupancy of trap sites: $\theta_{\mathrm{T}}=\mathrm{C}_{\mathrm{T}} /_{\mathrm{N}_{\mathrm{T}}}$ with $\mathrm{N}_{\mathrm{T}}=5 \times 10^{19}$ to $5 \times 10^{25} \mathrm{~m}^{-3}$ [38] the number of trap sites per unit volume and $\mathrm{K}_{\mathrm{T}}$ is the trap equilibrium constant. Hence, equation (21) can be written as function of $\mathrm{C}_{\mathrm{L}}, \mathrm{C}_{\mathrm{T}}, \mathrm{N}_{\mathrm{L}}$ and $\mathrm{N}_{\mathrm{T}}$.

$\ln \frac{\mathrm{C}_{\mathrm{T}}}{\mathrm{C}_{\mathrm{L}}}=-\ln \frac{\mathrm{N}_{\mathrm{L}}}{\mathrm{N}_{\mathrm{T}}-\mathrm{C}_{\mathrm{T}}}-\frac{\Delta \mathrm{E}_{\mathrm{T}}}{\mathrm{k}_{\mathrm{B}} \cdot \mathrm{T}}$

Moreover following a simple view of statistical distribution of diffusible hydrogen on lattice sites [35], the lattice hydrogen concentration can express as follow:

$\ln \frac{\mathrm{C}_{\mathrm{L}}}{\mathrm{N}_{\mathrm{L}}} \approx-\frac{\Delta \mathrm{E}_{\mathrm{L}}}{\mathrm{k}_{\mathrm{B}} \cdot \mathrm{T}}$

Figure 17: Evolution of $\ln \left(\mathrm{C}_{\mathrm{T}} / \mathrm{C}_{\mathrm{L}}\right)(\mathrm{a})$ and $\ln \left(\mathrm{C}_{\mathrm{L}} / \mathrm{N}_{\mathrm{L}}\right)(\mathrm{b})$ as a function of reciprocal temperature in $1 \mathrm{M} \mathrm{H}_{2} \mathrm{SO}_{4}$ under $-20 \mathrm{~mA} / \mathrm{cm}^{2}$ cathodic polarization

Equations (26) and (27) have been improved using data collected on Figure 15. Figure 17 shows $\ln \left(\mathrm{C}_{\mathrm{T}} / \mathrm{C}_{\mathrm{L}}\right)$ and $\ln \left(C_{L}\right)$ as a function of reciprocal temperature, $1 / T$. Linear regressions indicate a good correlation between the model (equations 26 and 27) and experimental data that permits to deduce $\Delta \mathrm{E}_{\mathrm{T}}, \Delta \mathrm{E}_{\mathrm{L}}$ and $\mathrm{N}_{\mathrm{L}}$. The energy $\Delta \mathrm{E}_{\mathrm{L}}$ is equal to $0.26 \mathrm{eV}$ which is in the same order of the one deduced from temperature dependence of the apparent diffusion coefficient $(0.26 \mathrm{eV}$, equation 20$)$. Thus, our presumption about the hydrogen diffusion is mainly linked to lattice diffusion is now confirmed. Using molecular dynamic calculation (DFT, Density Functional Theory) some authors reported for pure iron values of $\Delta \mathrm{E}_{\mathrm{L}}$ quite lower than our data $(0.2 \mathrm{eV}[50]$ and $0.1 \mathrm{eV}[51])$. The implication of lattice distortion (quadratic structure) and solute atoms (C, Mo) on diffusion process is reinforced. 
The number of lattice sites per unit volume, $\mathrm{N}_{\mathrm{L}}$ is equal to $1.45 \times 10^{29} \mathrm{~m}^{-3}$ which is lower than the one evaluated in the case of $\alpha$-iron: $\mathrm{N}_{\mathrm{L}}=5.1 \times 10^{29} \mathrm{~m}^{-3}$ [38]. The insertion of carbon on interstitial sites $\left(4.33 \times 10^{26} \mathrm{~m}^{-3}\right.$ for $0.45 \%$ wt $\mathrm{C}$ in the $\mathrm{Fe}-\mathrm{C}-\mathrm{Mo}$ steel $)$ and the substitution of iron atoms by molybdenum atoms $\left(1.62 \times 10^{27} \mathrm{~m}^{-3}\right.$ for $1.5 \% \mathrm{wt}$ Mo in the Fe-C-Mo steel) may reduce the number of lattice sites. $\Delta \mathrm{E}_{\mathrm{T}}$ deduced by equation (26) is equal to $0.32 \mathrm{eV}$ and consequently, the trapping energy is $\Delta \mathrm{E}_{\mathrm{TL}}=0.58 \mathrm{eV}\left(\Delta \mathrm{E}_{\mathrm{TL}}=\Delta \mathrm{E}_{\mathrm{L}}+\Delta \mathrm{E}_{\mathrm{T}}\right)$. When the occupancy of trapping sites by hydrogen is low $\left(\theta_{\mathrm{T}}<<1\right.$ which is the case here), the apparent diffusion coefficient becomes [37]:

$\mathrm{D}_{\mathrm{app}}=\mathrm{D}_{\mathrm{L}} \frac{1}{1+\exp \left(\frac{\Delta \mathrm{E}_{\mathrm{T}}}{\mathrm{k}_{\mathrm{B}} \mathrm{T}}\right) \cdot \frac{\mathrm{N}_{\mathrm{T}}}{\mathrm{N}_{\mathrm{L}}}}$

with $\mathrm{D}_{\mathrm{L}}=1.45 \times 10^{-9} \mathrm{~m}^{2} / \mathrm{s}, \Delta \mathrm{E}_{\mathrm{T}}=0.32 \mathrm{eV}, \mathrm{N}_{\mathrm{T}}=1.27 \times 10^{25} \mathrm{~m}^{-3}$ and $\mathrm{N}_{\mathrm{L}}=1.45 \times 10^{29} \mathrm{~m}^{-3}$. As shown on Figure 18 , Oriani model seems to be in accordance with the evolution of experimental data as a function temperature in the considered range. However, Oriani model is in agreement with only reversible trap evolution (Figure 11a). This suggests that the evolution of the apparent diffusion coefficient is mainly affected by diffusible hydrogen i.e. with a contribution of interstitial and reversible trapped hydrogen in the range of explored concentration (0.24ppm wt for a $-20 \mathrm{~mA} / \mathrm{cm}^{2}$ cathodic polarization at $\left.293 \mathrm{~K}\right)$.

Figure 18: Experimental and modeling curves of the apparent diffusion coefficient in the Fe-C-Mo HSLA steel as a function of the temperature in $1 \mathrm{M} \mathrm{H}_{2} \mathrm{SO}_{4}$ under $-20 \mathrm{~mA} / \mathrm{cm}^{2}$ cathodic polarization

\section{Discussions}

Experimental results highlight that the microstructure, the cathodic current density and the temperature affected the hydrogen diffusion and trapping processes. The microstructure of quenched and tempered martensite was characterized in the Fe-C-Mo alloy by using transmission electron microscopy and electron back-scattered diffraction. Different heterogeneousness scales were determined as potential trapping sites: the macroscopic scale (grain boundaries, prior $\gamma$ grains), the lath scale (interface density, lath size), the precipitate scale (precipitate density, coherent/incoherent precipitate, strain field) and the dislocation scale (dislocation density, hydrostatic pressure). All of these parameters are summarized in table 1. Figure 19 illustrates the trapping energy $\Delta \mathrm{E}_{\mathrm{TL}}$ for each scale of trapping sites according to literature data.

Figure 19: Trap binding energy for a martensitic microstructure

Therefore, hydrogen diffusion trapping can be discussed on the basis of microstructural observations and results from the electrochemical permeation tests. In this work, electrochemical permeation tests at $293 \mathrm{~K}$ with a large scale of charging conditions lead to an augmentation of the apparent diffusion coefficient as a function of the apparent subsurface concentration. For high value of $<\mathrm{C}>, \mathrm{D}_{\text {app }}$ remains quite constant at about $7.4 \times 10^{-11} \mathrm{~m}^{2} / \mathrm{s}$ corresponding to a steady-state associated with interstitial diffusion. The evolution of $\mathrm{D}_{\text {app }}$ is linked to two kinetic processes depending on the charging conditions and on the temperature (thermically activated process). The kinetics of diffusion and trapping processes are responsible for the evolution of $\mathrm{D}_{\text {app }}$. Indeed, at a given temperature, two prominent effects of trapping are the increase of the apparent hydrogen solubility (table 2) and 
the amplification of the apparent diffusion coefficient (Figure 9, domain I). Consequently the hydrogen behavior in domain I can be associated to the trapping process in presence of segregated elements. Without the trapping process, $D_{\text {app }}$ should be independent of the hydrogen solubility as it had been shown on single palladium crystals [35]. When all segregated sites are filled, lattice diffusion may occur and the value of apparent diffusion coefficient is the hydrogen diffusion coefficient D in the metal (domain II). The equilibrium between diffusible and trapped hydrogen is defined by kinetics constant of trapping $\left(\mathrm{k}_{\mathrm{t}}\right)$ and releasing $\left(\mathrm{k}_{\mathrm{r}}\right)$. The trap binding energy is higher for releasing processes $\left(\mathrm{k}_{\mathrm{r}}<\mathrm{k}_{\mathrm{t}}\right)$ i.e. the probability of hydrogen mobility is diminished in presence of segregated sites. The reduction of the amount of trapping sites increases the hydrogen mobility thus a raise of the apparent diffusion coefficient in domain I. In addition, the expression of the apparent diffusion coefficient allows to determine a lattice coefficient diffusion $\mathrm{D}_{\mathrm{L}}=1.45 \times 10^{-9} \mathrm{~m}^{2} / \mathrm{s}$ (phenomenological analyses) which is lower than the value of the lattice diffusivity of hydrogen in $\alpha$-iron $\left(\mathrm{D}_{\mathrm{Fe} \alpha} \approx 10^{-8}\right.$ to $\left.10^{-9} \mathrm{~m}^{2}\right)$. When the austenite phase $(\gamma)$ with a face-centered cubic (fcc) structure is quickly quenched to low temperatures, a displacive transformation forms martensite with a body-centered cubic (bcc) or body-centered tetragonal structure. The transformation to martensite engenders the distortion of the crystal by interstitial carbon atoms that do not have time to diffuse during displacive transformation. Evolutions of lattice parameters (a and c), which depend on the carbon content, are given by the Kurdjumov equation $\mathrm{c} / \mathrm{a}=1+0,046 \times \mathrm{C} \%(\mathrm{wt})$. The distortion of the crystal may occasion elastic fields near lattice diffusion sites and may interfere with the hydrogen mobility by acting as trapping sites. Hence the lower value of our lattice coefficient diffusion compared to the hydrogen lattice diffusivity in $\alpha$-iron might be explained. Moreover, the magnitude of carbon atoms in interstitial sites $\left(4.33 \times 10^{26} \mathrm{~m}^{-3}\right)$ and the substitution of iron atoms by molybdenum atoms $\left(1.62 \times 10^{27} \mathrm{~m}^{-3}\right)$ will reduce the number of lattice sites and consequently the hydrogen diffusion process.

Electrochemical permeation tests under $-20 \mathrm{~mA} / \mathrm{cm}^{2}$ cathodic polarizations at four temperatures $(283,293,303$ and $313 \mathrm{~K}$ ) revealed a rise of the apparent diffusion coefficient and a decrease of the total number of trapped hydrogen. It was shown that diffusion and trapping are thermically activated processes. The use of Arrhenius model for diffusion process leads to $\mathrm{D}_{0}=3.68 \times 10^{-5} \mathrm{~m}^{2} / \mathrm{s}$ and an activation energy of diffusion process of $\mathrm{E}_{\mathrm{D}}=0.26 \mathrm{eV}$. Using trap models $[37,38,48,49]$, the trapping energy is evaluated to $\Delta \mathrm{E}_{\mathrm{TL}}=0.58 \mathrm{eV}$. The latter is representative of the major trapping site in the membrane. These values are supposed to be representative to a deep trapping on dislocation core associated with incidental dislocation in intra-lath and/or on martensitic lath interfaces due to misorientations (geometric necessary dislocations). The trapping energy has been estimated to be respectively $\Delta \mathrm{E}_{\mathrm{TL} \text { (dislocation core) }}=0.58 \mathrm{eV}$ [53] and $\Delta \mathrm{E}_{\mathrm{TL} \text { (dislocation in lath interface) }}=0.52$ [16] to $0.62 \mathrm{eV}$ [54]. Intra-lath dislocation density $\left(\rho_{\mathrm{d}}=3.25 \times 10^{14} \mathrm{~m}^{-2}\right)$ has been quantified by microstructural characterizations and is not negligible. The core of an edge dislocation should be a reversible trap at ambient and low temperatures [53, 56] which is in agreement with our study. Moreover, it has been demonstrated by molecular statics analyses that hydrogen atoms exist on the edge dislocation along the slip plane near the dislocation core [57]. However, only the reversible trapped hydrogen can be adjusted by the Oriani model (Figure 11a). The apparent subsurface concentration of hydrogen due to a $-20 \mathrm{~mA} / \mathrm{cm}^{2}$ cathodic polarization $(\approx 0.24 \mathrm{ppm}$ wt) belongs to domain I', (Figure 11b) where both reversible and irreversible traps have an influence. So the hydrogen diffusivity is mainly controlled by moving hydrogen (interstitial and reversible) in the studied hydrogen concentrations range. This outline is in good agreement with the fact that dislocations, which are reversible traps, might be the major trapping site. As a consequence, it is necessary to detail this investigation for lower and higher apparent 
subsurface concentrations in order to access different parameters which enable to characterize the first subdomain I' $(<\mathrm{C}><0.12 \mathrm{ppm} w \mathrm{wt})$ and domain II $(<\mathrm{C}>>0.5 \mathrm{ppm} w \mathrm{wt})$.

In addition, using only one composition of steel it might expand the difficulty of getting the trapping sites. Thus, it is necessary to work with another grade or another heat treatment to determine the major trapping site in this range of temperatures. Moreover, we supposed that all interstitial or reversible trapped hydrogen are released on the exit side of the membrane which is a fundamental hypothesis considering that a part of hydrogen may diffuse toward the entry side.

\section{Conclusions}

Diffusion and trapping of hydrogen has been studied through a Fe-C-Mo quenched and tempered high strength low alloy steel (HSLA). Microstructural characterizations from optical microscopy to transmission electron microscopy enable to define various scales of potential trap sites: grains and lathes boundaries, precipitation states and dislocations.

To understand the interaction of hydrogen with steel, the electrochemical permeation technique is used. The increase of the charging current density generates higher steady-state permeation rates thus hydrogen flux is sensitive to an augmentation of the hydrogen subsurface concentration. The apparent diffusion coefficient evolves with the subsurface concentration of hydrogen. Two domains appear and are mainly associated with a competition between two distinct processes with quite different kinetics: hydrogen trapping and hydrogen diffusion. The growth of the apparent hydrogen concentration induces a gain of the apparent diffusion coefficient until a constant value $\mathrm{D}_{\mathrm{app}} \approx 7.4 \times 10^{-11} \mathrm{~m}^{2} / \mathrm{s}$ which corresponds to a lattice diffusion coefficient $\mathrm{D}_{\mathrm{L}}=1.45 \times 10^{-9} \mathrm{~m}^{2} / \mathrm{s}$.

Analyses of trapping processes permit us to thoroughly understand the interactions between different hydrogen species: diffusible hydrogen, reversible trapped hydrogen and irreversible trapped hydrogen. The amount of hydrogen species spreads with the apparent hydrogen subsurface concentration and the hydrogen distribution is strongly dependent on the cathodic charging conditions. The total trapped hydrogen may reach up to $96 \%$ of the total hydrogen concentration and the hydrogen diffusivity is mainly influenced by diffusible hydrogen (interstitial hydrogen and reversible trapped hydrogen). The evolution of the total trapped hydrogen with temperature allows to establish the nature of trapping sites. Using results from the literature and from microstructural characterizations, the trapping energy $\Delta \mathrm{E}_{\mathrm{TL}}=0.58 \mathrm{eV}$ leads to the determination of the edge dislocations cores and/or geometrical necessary dislocations as the major trapping site.

This present work is mainly based on modeling of the experimental permeation results in order to get information about the distribution of lattice diffusion and trapping sites in the material. However, these observations should be confirmed by using Thermal Desorption Spectroscopy (TDS).

\section{Acknowledgement}

The authors thank the CCA (Centre Commun d'Analyses) and Egle Conforto, Université de La Rochelle, for electron microscopy facilities. 
8. References

[1]
J.L. Crolet, La revue de métallurgie (2001) 501-518

F.W.H. Dean, Mater. Sci. Technol. 21 (n³) (2005) 347-351

J. Kittel, F. Ropital, J. Pellier, Corrosion2008, NACE conf. Series, paper nº8409 (2008)

G.T.Park, S.U.Koh, H.G. Jung, K.Y.Kim, Corros. Sci. 50 (2008) 1865-1871

F.H.Heubaum, B.J. Berkowitz, Scripta Metall.16 (1982) 659-662

T. Casanova, J. Crousier, Corros. Sci. 38 (n9) (1996) 1535-1544

H. Addach, Thèse de Doctorat, U.F.R des Sciences et Techniques de l'Université de FrancheComté (2006) 170

M.A.V Devanathan, Z. Stachursky, J. Electrochem. Soc. 111 (n5) (1964) 619-623

P. Manolatos, Thèse de Doctorat, Ecole Nationale supérieure des Mines de Paris, (1989) 279

P. Manolatos, M. Jerome, J. Galland, Electrochim. Acta 40 (nº7) (1995) 867-871

P. Manolatos, M. Jerome, Electrochim. Acta 41 (n³) (1996) 359-365

N. Parvathavarthini, S. Saroja, R.K. Dayal, J. Nucl. Mater. 264 (1999) 35-47

B.D. Craig, Acta Metall. 25 (1977) 1027-1030

M.I. Luppo, J. Ovejero-Garcia, Corros. Sci. 32 (n¹0) (1991) 1125-1136

W.C. Luu, J.K. Wu, Corros. Sci. 38 (n²) (1996) 239-245

N. Parvathavarthini, S. Saroja, R.K. Dayal, H.S. Khatak, J. Nucl. Mater. 288 (2001) 187-196

B.G. Pound, Acta Mater. $46\left(n^{\circ} 16\right)$ (1998) 5733-5743

K. Banerjee, U.K. Chetterjee, Scripta Mater. 44 (2001) 213-216

S. Serna, H. Martinez, S.Y. Lopez, J.G Gonzalez-Rodriguez, J.L. Albarran, Int. J. Hydrogen Energy 30 (2005) 1333-1338

V.P. Ramunni, T. De Paiva Coelho, P.E.V. de Miranda, Mater. Sci. Eng. A 435-436 (2006) 504-514

W.K. Kim, S.U. Koh, B.Y. Yang, K.Y. Kim, Corros. Sci. 50 (n¹2) (2008) 3336-3342

V. Olden, C. Thaulow, R. Johnsen, Mater. Des. 29 (2008) 1934-1948

M.A.V Devanathan, Z. Stachursky, The Royal Society 270 (1962) 90-102

J. McBreen, L. Nanis, W. Beck, J. Electrochem. Soc. 113 (n¹1) (1966) 1218-1222

H. El Alami, J. Creus, X. Feaugas, Electrochim. Acta 51 (n²2) (2006) 4716-4727

M. Jérôme, Mémoire d'HDR, Université de Technologie de Compiègne (2003)

J. Bouhattate, S. Frappart, X. Feaugas, Comsol Conf. 2009, Milan (2009)

T. Zakroczymski, Electrochim. Acta 51(n¹1) (2006) 2261-2266 
S.M. Charca, O.N.C Uwakweh, V.S. Agarwala, Metall. Mater. Trans. A 38A (2007) 23892399 Y.F. Cheng, Int. J. Hydrogen Energy 32 (2006) 1269-1276

C. Ly, Thèse de Doctorat, Ecole Centrale Paris (2009) 189

R.Kirchheim, Prog. Mater. Sci. 32 (1988) 261-325

D.S. Dos Santos, P.E.V. De Miranda, Int. J. Hydrogen Energy 23 (1998) 1011-1017

R.A. Oriani, Acta Metall. 18 (1970) 147-157

A.H.M. Krom, A.D. Bakker, Metall. Mater. Trans. B 31B (2000) 1475-1482

S. Wach, A.P. Miodownik, J. Mackowiak, Corros. Sci. 6 (1966) 271-285

B.S. Chaudari, T.P. Radakrishnan, Corros. Sci. 30 (n¹2) (1990) 1219-1234

H.J. Grabke, E. Riecke, Mater. Tehnol. 34 (2000) 331-342

H. Addach, P. Berçot, M. Rezrazi, M. Wery, Mater. Lett. 59 (2005) 1347-1351

A.M. Sukhotin, E.V. Sapelova, M.D. Reingeverts, Corros. Sci. 25 (n²) (1985) 93-98

P. Bruzzoni, R. Garavaglia, Corros. Sci. 33 (n³) (1992) 1797-1807

J.Philibert, Diffusion et transport de matière dans les solides, Les éditions de physique (2003)

G.A. Esteban. A. Pena, I. Urra, F. Legarda, B. Riccardi, Fusion Eng. Des. 82 (2007) 2634-2640

F.-G. Wei, K. Tsuzaki, Scripta Mater. 52 (2005) 467-472

A.J. Kumnick, A.H. Johnson, Acta Metall. 28 (1980) 33-39

A. McNabb, P.K. Foster, Trans. Metall. Soc. AIME 227 (1963) 618-627

D.E. Jiang, E.A. Carter, Phys. Rev. B 70 (2004) 1-9

V.P. Ramunni, R.C. Pasianot, P. Bruzzoni, Physica B 404 (2009) 2880-2882

H. Dogan, D. Li, J.R. Scully, Corros. Sci. 63 (nº7) (2007) 689-703

R.L.S. Thomas, D. Li, R.P. Gangloff, J.R. Scully, Metall. Mater. Trans. A 33A (2002) 19912004

R. Matsumoto, S. Taketomi, N. Miyazaki, Y. Inoue, M. Riku, Int. Hydrogenius symposium 2009: Hydrogen-materials interaction (2009)

W.Y Choo, J.Y Lee, Metall. Trans. A 13A (1982) 135-140

M.E. Glicksmann: Diffusion in solids, filed theory, solid-state principles, and applications, Wiley-Interscience Publication, ISBN: 0-471-23972-0 (2000)

S. Taketomi, R. Matsumoto, N.Miyazaki, Acta Mater. 56 (2008) 3761-3769 
Table 1: Microstructural characterization of the Fe-C-Mo HSLA martensitic steel

\begin{tabular}{|cccccc|}
\hline $\begin{array}{c}\text { Prior } \gamma \\
\text { grain size }\end{array}$ & $\begin{array}{c}\text { Maximal lath } \\
\text { length }\end{array}$ & $\begin{array}{c}\text { Minimal lath } \\
\text { length }\end{array}$ & $\begin{array}{c}\text { Precipitate } \\
\text { density }\end{array}$ & $\begin{array}{c}\text { Interface } \\
\text { density }\end{array}$ & $\begin{array}{c}\text { Dislocation } \\
\text { density }\end{array}$ \\
\hline$\mu \mathrm{m}$ & $\mu \mathrm{m}$ & $\mu \mathrm{m}$ & $\mu \mathrm{m}^{-2}$ & $\mu \mathrm{m} / \mu \mathrm{m}^{2}$ & $\mathrm{~m}^{-2}$ \\
\hline 30 & 3.3 & 0.5 & 2.4 & 3 & $3.25 \times 10^{14}$ \\
\hline
\end{tabular}


Table 2: Hydrogen permeation results in Fe-C-Mo steel under cathodic polarization in $1 \mathrm{M} \mathrm{H}_{2} \mathrm{SO}_{4}$ at $293 \mathrm{~K}$

\begin{tabular}{|cccc|}
\hline Charging Current density $\left(\mathrm{mA} / \mathrm{cm}^{2}\right)$ & $\mathrm{j}_{\infty}\left(\mu \mathrm{A} / \mathrm{cm}^{2}\right)$ & $\mathrm{D}_{\text {app }} \cdot 10^{11}\left(\mathrm{~m}^{2} / \mathrm{s}\right)$ & $<\mathrm{C}>(\mathrm{ppm} w \mathrm{w})$ \\
\hline $5(\mathrm{~V})$ & 0.46 & 4.10 & 0.14 \\
$10(\mathrm{~V}+\mathrm{H})$ & 0.61 & 4.60 & 0.18 \\
$20(\mathrm{~V}+\mathrm{H})$ & 0.81 & 5.40 & 0.24 \\
$125(\mathrm{~V}+\mathrm{H})$ & 1.36 & 6.20 & 0.33 \\
$175(\mathrm{H})$ & 1.97 & 7.50 & 0.40 \\
$200(\mathrm{H})$ & 3.65 & 7.85 & 0.94 \\
\hline
\end{tabular}

V: Volmer H: Heyrovsky 
Table 3: Hydrogen permeation results in Fe-C-Mo steel under $-20 \mathrm{~mA} / \mathrm{cm}^{2}$ cathodic polarization in $1 \mathrm{M} \mathrm{H}_{2} \mathrm{SO}_{4}$ at $283,293,303$ and $313 \mathrm{~K}$

\begin{tabular}{|ccc|}
\hline Temperature $(\mathrm{K})$ & $\mathrm{D}_{\mathrm{app}} \cdot 10^{11}\left(\mathrm{~m}^{2} / \mathrm{s}\right)$ & $<\mathrm{C}>(\mathrm{ppm} \mathrm{wt})$ \\
\hline 283 & 3.37 & 0.32 \\
293 & 4.94 & 0.47 \\
303 & 6.25 & 0.42 \\
313 & 9.52 & 0.18 \\
\hline
\end{tabular}




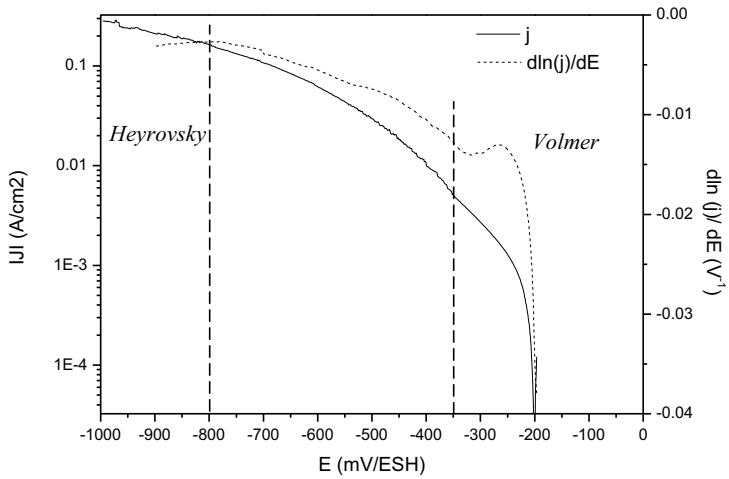

(a)

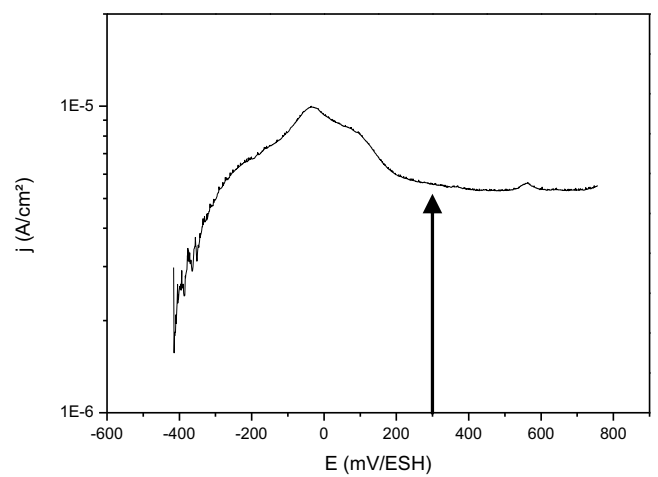

(b)

Figure 1: Polarization curves in $1 \mathrm{M} \mathrm{H}_{2} \mathrm{SO}_{4}$ (a) and in $0.1 \mathrm{M} \mathrm{NaOH}$ (b) on Fe-C-Mo samples at $293 \mathrm{~K}$ and $\mathrm{S}=1 \mathrm{~cm}^{2}$ 

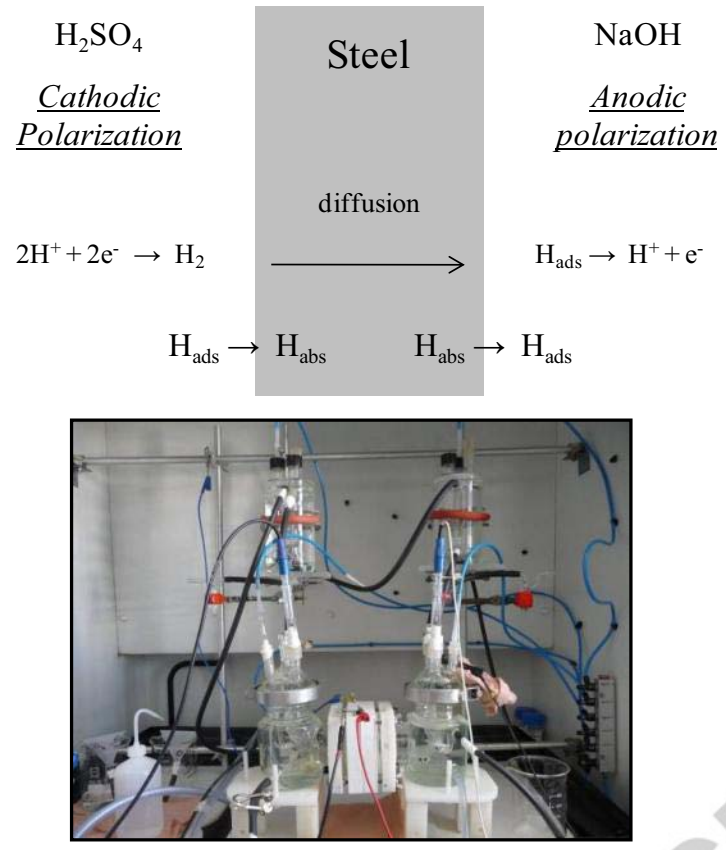

Figure 2: Scheme and device of the electrochemical permeation test 


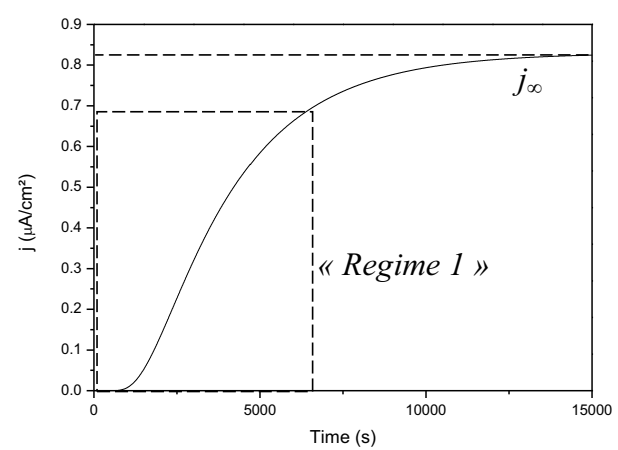

(a)

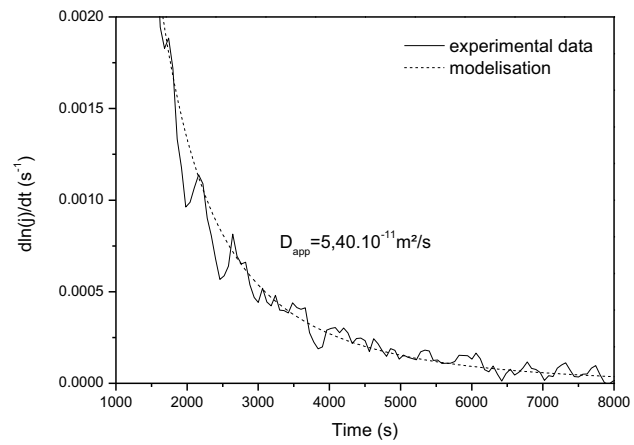

(c)

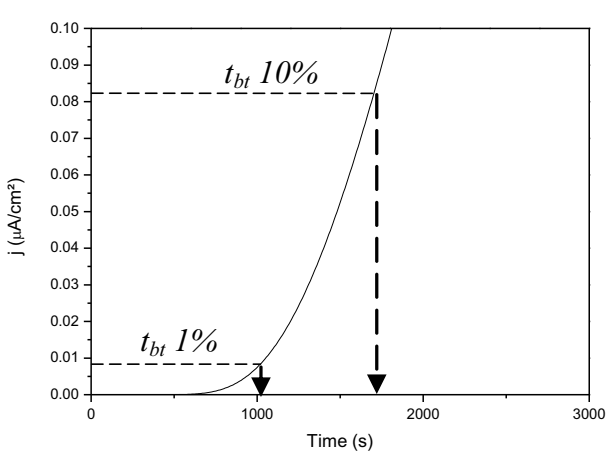

(b)

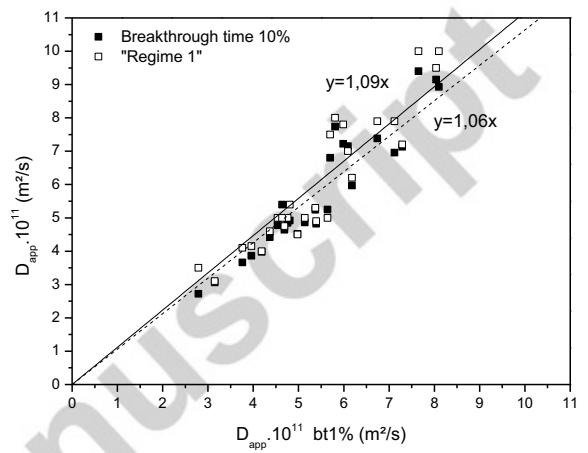

(d)

Figure 3: Experimental (a, b) and adjusted experimental data (c) for the Fe-C-Mo model steel under a $20 \mathrm{~mA} / \mathrm{cm}^{2}$ cathodic polarization in $1 \mathrm{M} \mathrm{H}_{2} \mathrm{SO}_{4}$ at $293 \mathrm{~K}$ and the correlation (d) between the different methods of determination of the apparent diffusion coefficient as function of the apparent diffusion coefficient obtained by the breakthrough time at $1 \%$ of the steady state current. 


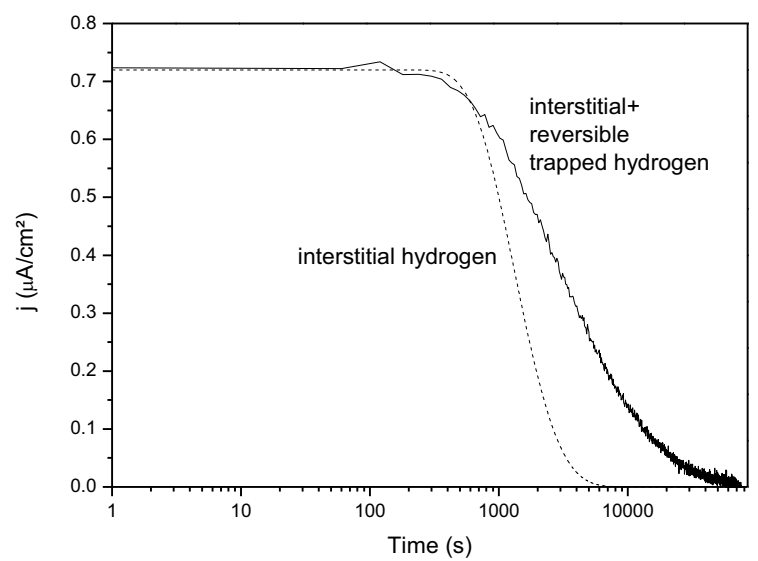

Figure 4: Analysis of the hydrogen desorption from the Fe-C-Mo model steel on the exit side after a $-20 \mathrm{~mA} / \mathrm{cm}^{2}$ cathodic polarization in $1 \mathrm{M} \mathrm{H}_{2} \mathrm{SO}_{4}$ at $293 \mathrm{~K}$ 


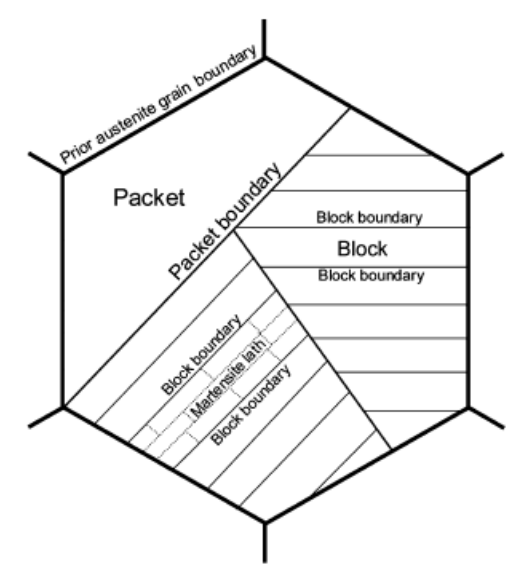

Figure 5: Microstructural hierarchy of a martensitic microstructure [29] 


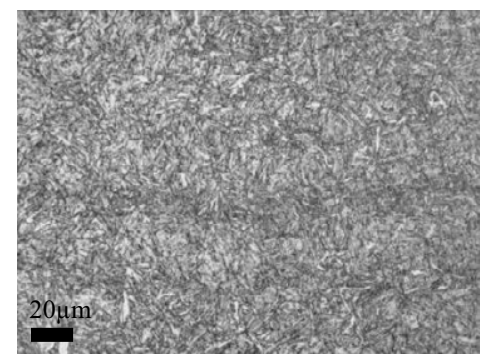

(a)

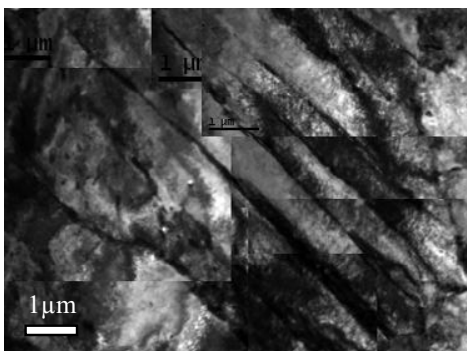

(c)

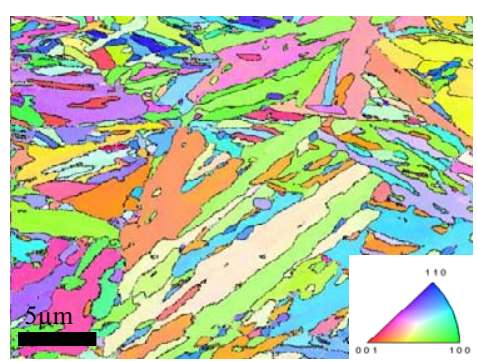

(b)

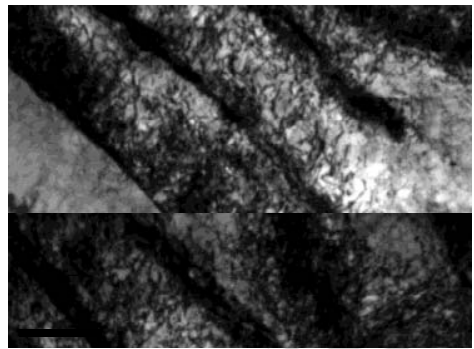

(d)

Figure 6: Optical (a), EBSD (b) and TEM micrographs (c,d) of the specimen 

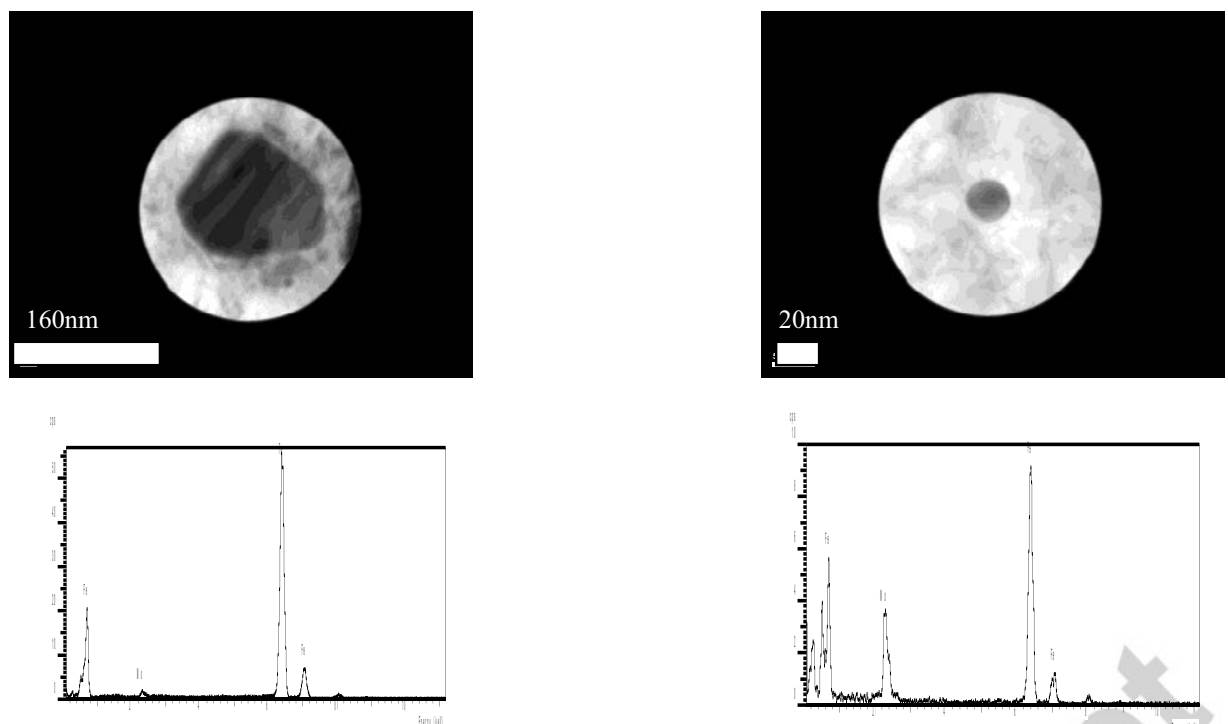

(a)

(b)

Figure 7: Inter lathes precipitation characterizations by TEM and XRD: a - Cubic carbide $\tau$ (ex: $\left.\mathrm{Fe}_{21} \mathrm{Mo}_{2} \mathrm{C}_{6}\right)$

$\mathrm{b}-$ Orthorhombic carbide $\xi\left(\mathrm{ex}: \mathrm{Fe}_{2} \mathrm{MoC}\right.$ ) or/and cubic carbide $\eta\left(\mathrm{ex}: \mathrm{M}_{6} \mathrm{C}\right.$ ) 


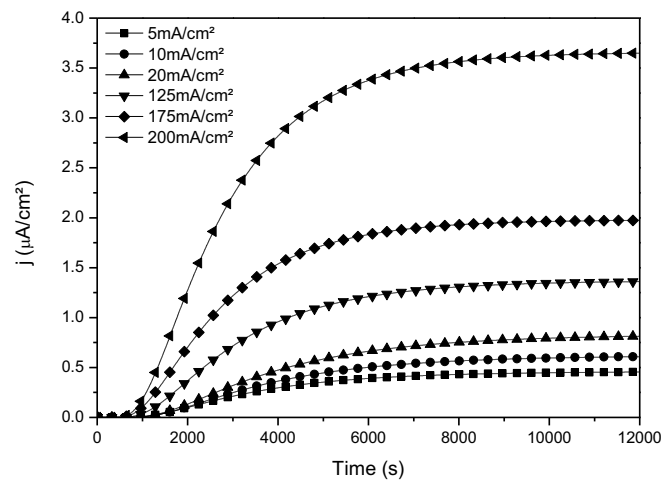

(a)

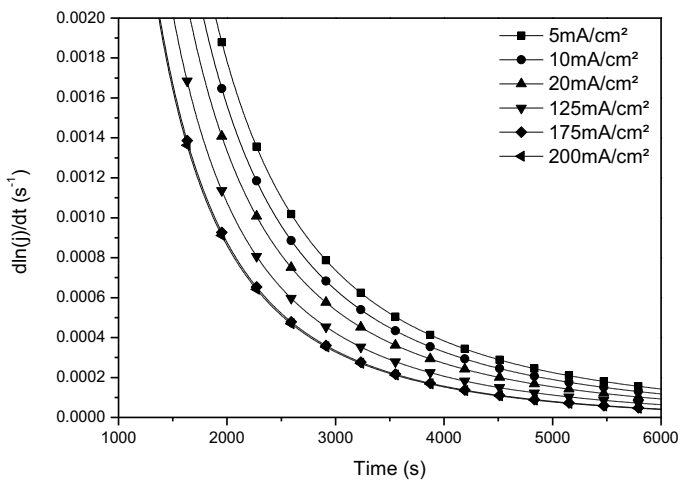

(b)

Figure 8: Permeation transient $\mathrm{j}=\mathrm{f}(\mathrm{t})$ (a) and the experimental " $1{ }^{\mathrm{st}}$ Regime" $\frac{\partial \ln (J)}{\partial t}=\mathrm{f}(\mathrm{t})$ (b) for the Fe-C-Mo steel membrane under cathodic polarization in $1 \mathrm{M} \mathrm{H}_{2} \mathrm{SO}_{4}$ at $293 \mathrm{~K}$ 


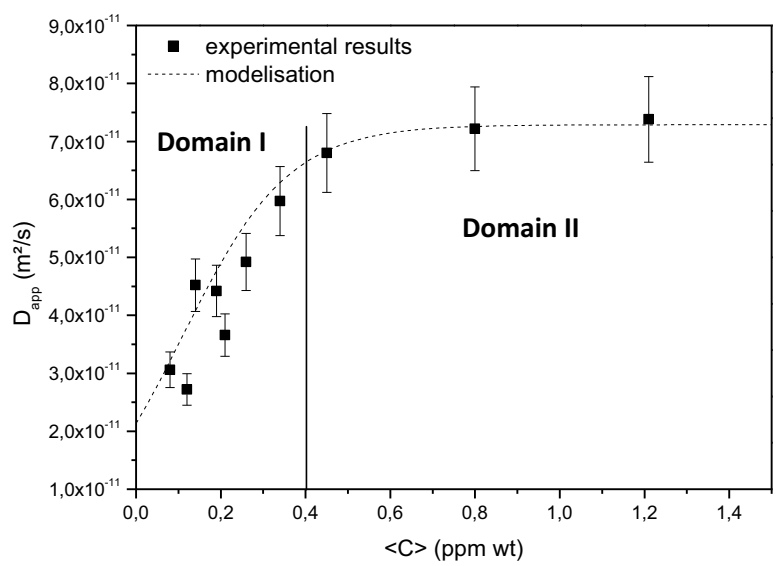

Figure 9: Apparent diffusion coefficient in the Fe-C-Mo HSLA steel as a function of the apparent subsurface concentration of hydrogen at $293 \mathrm{~K}$ 


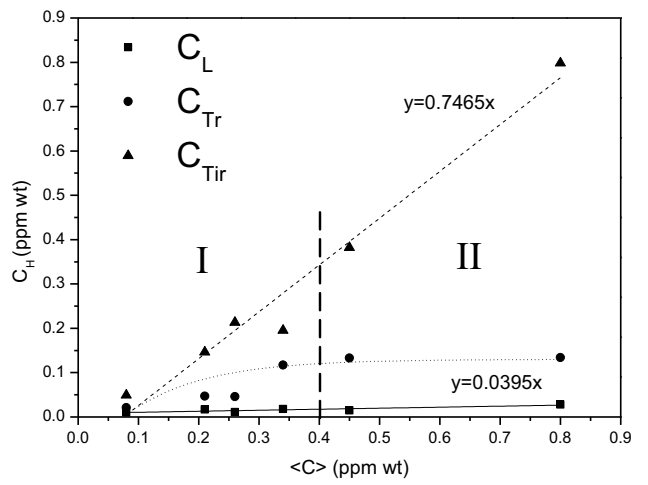

Figure 10: Evolution of irreversible, reversible trapped and lattice hydrogen as a function of the apparent subsurface concentration of hydrogen under cathodic polarization at $293 \mathrm{~K}$ 


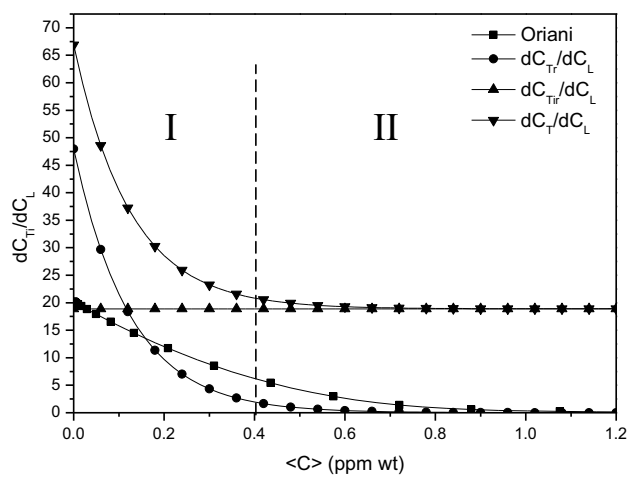

(a)

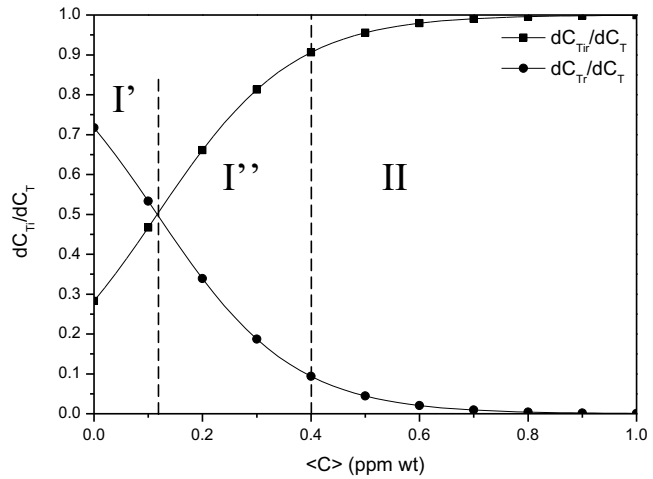

(b)

Figure 11: Evolution of the partial derivatives of the hydrogen concentration in trapping sites $\mathrm{C}_{\mathrm{T}}$ with respect to the hydrogen concentration in lattice $\mathrm{C}_{\mathrm{L}}$ sites (a) and evolution of the partial derivatives of the hydrogen concentration in trapping sites $\mathrm{C}_{\mathrm{Ti}}$ with respect to the total hydrogen concentration in trapping sites $\mathrm{C}_{\mathrm{T}}(\mathrm{b})$ in the Fe-C-Mo HSLA steel cathodic polarization at $293 \mathrm{~K}$ 


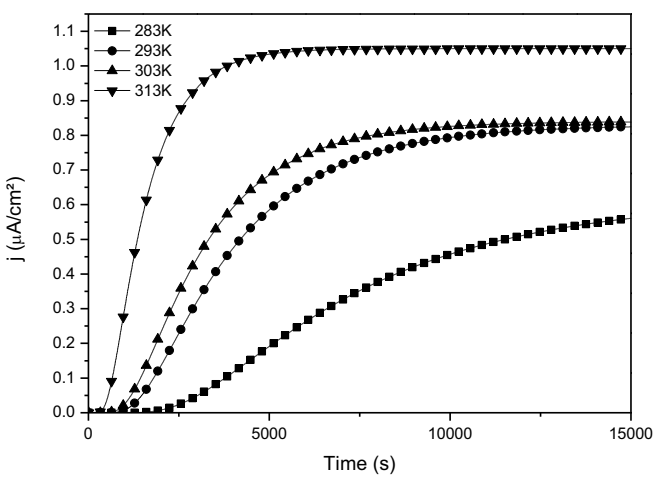

(a)

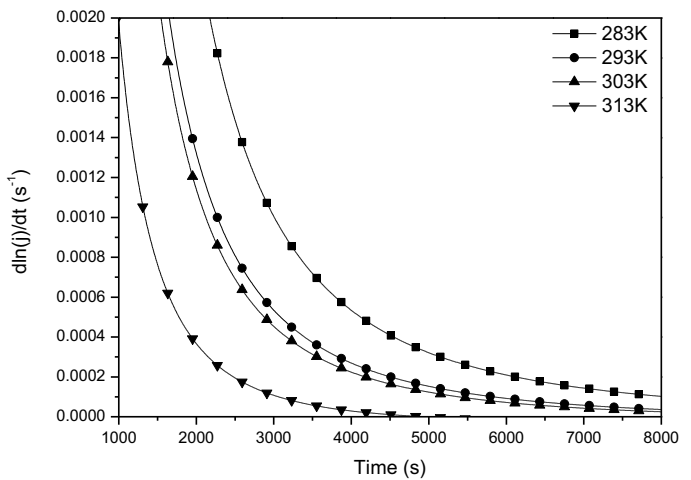

(b)

Figure 12: Permeation transient $\mathrm{j}=\mathrm{f}(\mathrm{t})$ (a) and the experimental " $1{ }^{\text {st }}$ Regime" $\frac{\partial \ln (J)}{\partial t}=\mathrm{f}(\mathrm{t})$ (b) for the Fe-C-Mo steel membrane under $-20 \mathrm{~mA} / \mathrm{cm}^{2}$ cathodic polarization in $1 \mathrm{M} \mathrm{H}_{2} \mathrm{SO}_{4}$ at $283,293,303$ and $313 \mathrm{~K}$ 


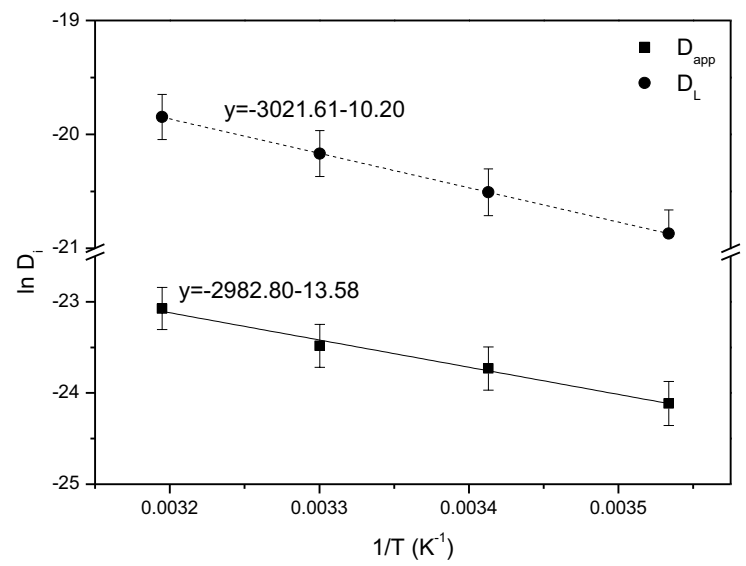

Figure 13: Evolution of the apparent and lattice diffusion coefficients in Fe-C-Mo steel as a function of reciprocal temperature adjusted with an Arrhenius law under $-20 \mathrm{~mA} / \mathrm{cm}^{2}$ cathodic polarization in $1 \mathrm{M} \mathrm{H}_{2} \mathrm{SO}_{4}$ 


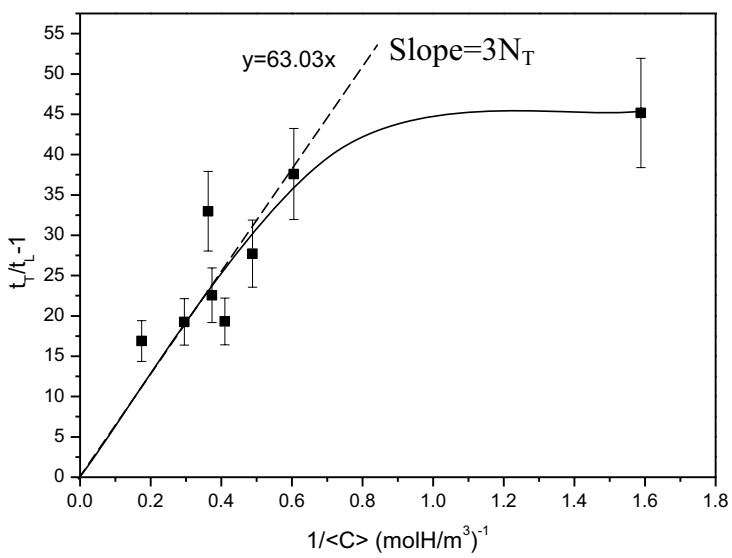

Figure 14: Evolution of $t_{\mathrm{T}} / \mathrm{t}_{\mathrm{L}}-1$ as a function of reciprocal hydrogen concentration for the Fe-C-Mo steel membrane under cathodic polarization in $1 \mathrm{M} \mathrm{H}_{2} \mathrm{SO}_{4}$ at $293 \mathrm{~K}$ 


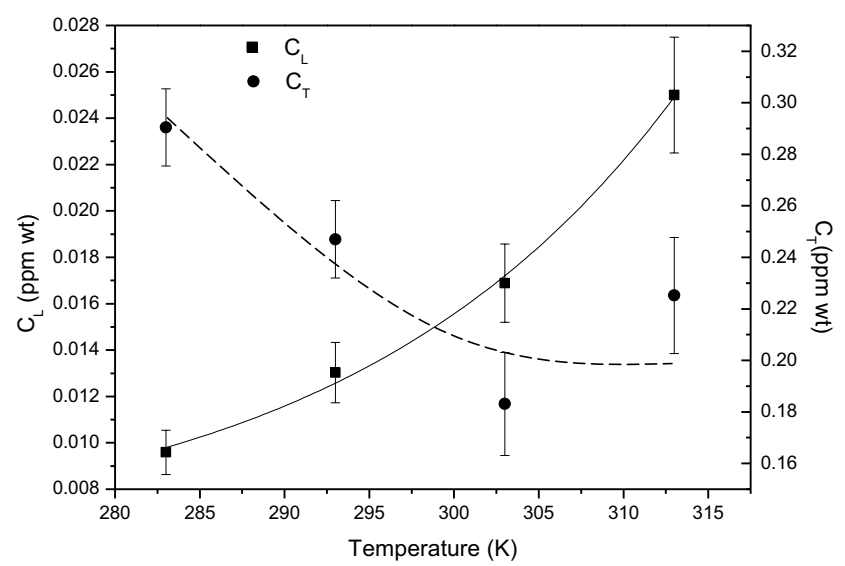

Figure 15: Evolution of diffusible and total trapped hydrogen (a) and irreversible/reversible trapped hydrogen (b) as a function of temperature in $1 \mathrm{M} \mathrm{H}_{2} \mathrm{SO}_{4}$ under $-20 \mathrm{~mA} / \mathrm{cm}^{2}$ cathodic polarization 


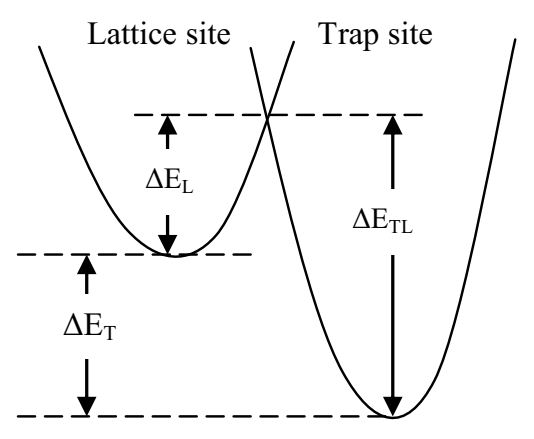

Figure 16: Schematic view of energy relations in hydrogen-metal system 


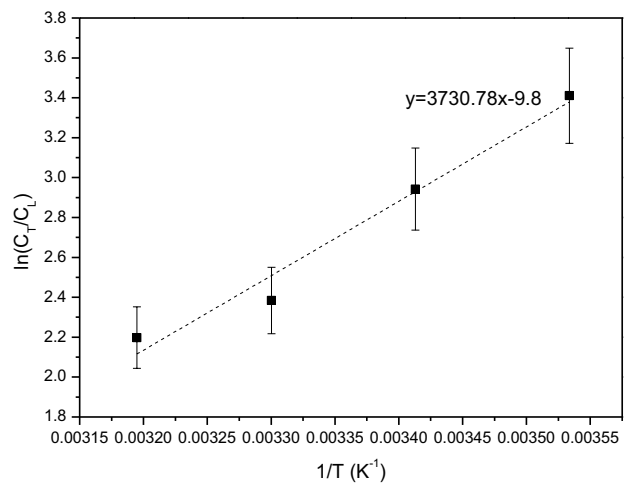

(a)

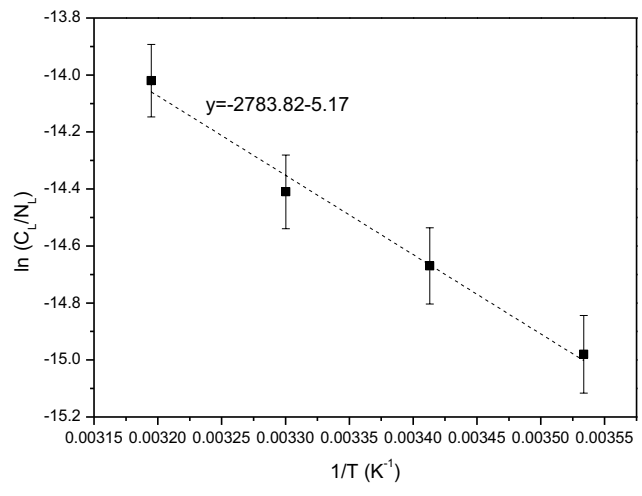

(b)

Figure 17: Evolution of $\ln \left(\mathrm{C}_{\mathrm{T}} / \mathrm{C}_{\mathrm{L}}\right)$ (a) and $\ln \left(\mathrm{C}_{\mathrm{L}} / \mathrm{N}_{\mathrm{L}}\right)$ (b) as a function of reciprocal temperature in $1 \mathrm{M} \mathrm{H}_{2} \mathrm{SO}_{4}$ under $-20 \mathrm{~mA} / \mathrm{cm}^{2}$ cathodic polarization 


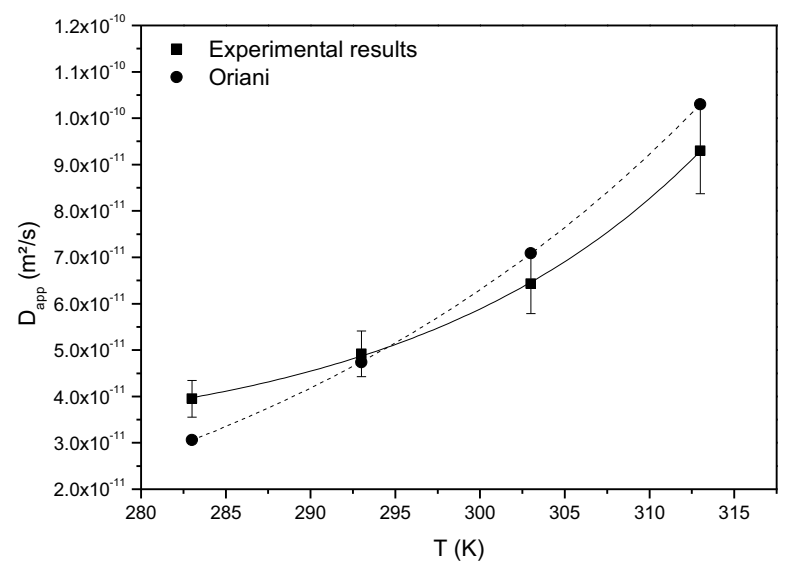

Figure 18: Experimental and modeling curves of the apparent diffusion coefficient in the Fe-C-Mo HSLA steel as a function of the temperature in $1 \mathrm{M} \mathrm{H}_{2} \mathrm{SO}_{4}$ under $-20 \mathrm{~mA} / \mathrm{cm}^{2}$ cathodic polarization 


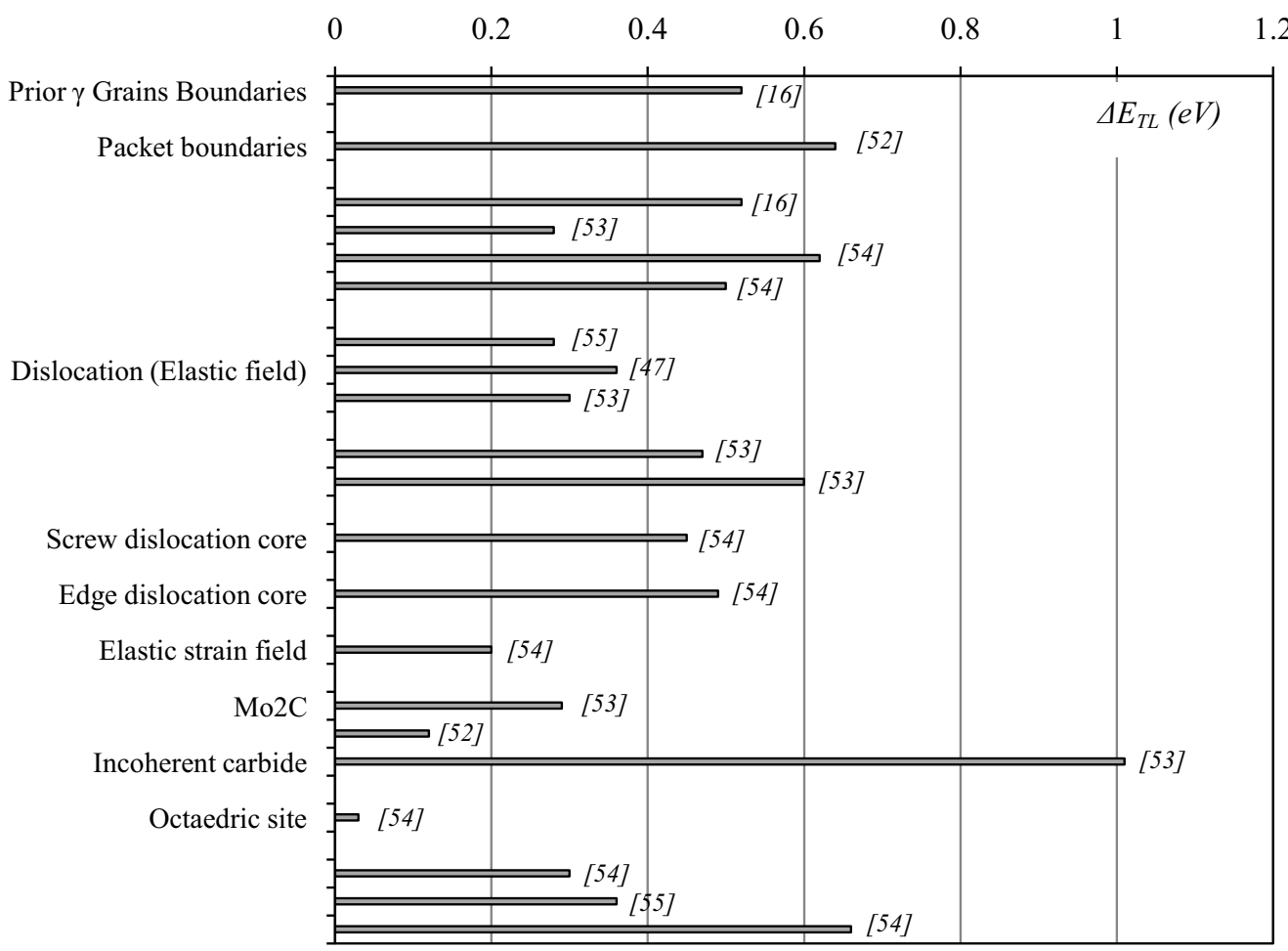

Figure 19: Trap binding energy for a martensitic microstructure 